\title{
Late Pleistocene lake level, glaciation and climate change in the Mongolian Altai deduced from sedimentological and palynological archives
}

\author{
Michael Klinge ${ }^{a *}$ (D), Frank Schlütz ${ }^{\mathrm{b}}$, Anja Zander ${ }^{\mathrm{c}}$, Daniela Hülle ${ }^{\mathrm{d}}$, Ochirbat Batkhishig ${ }^{\mathrm{e}}$, Frank Lehmkuhl ${ }^{\mathrm{f}}$ \\ anstitute of Geography, University of Göttingen, Goldschmidtstr. 5, D-37077 Göttingen, Germany \\ ${ }^{\mathrm{b}}$ Lower Saxony Institute for Historical Coastal Research, D-26382 Wilhelmshaven, Germany \\ ${ }^{c}$ Institute of Geography, University of Cologne, Albertus-Magnus-Platz, D-50923 Cologne, Germany \\ dinstitute of Geology, University of Cologne, Albertus-Magnus-Platz, D-50923 Cologne, Germany \\ ${ }^{\mathrm{e}}$ Institute Geography-Geoecology, Mongolian Academy of Science, Ulaanbaatar 14192, Mongolia \\ ${ }^{\mathrm{f}}$ Department of Geography, RWTH Aachen University, D-52056 Aachen, Germany \\ *Corresponding author at: Institute of Geography, University of Göttingen, Goldschmidtstrasse 5, D-37077 Göttingen, Germany. E-mail address: mklinge1@ \\ gwdg.de (M. Klinge).
}

(Received January 13, 2020; AcCEPTED July 1, 2020)

\begin{abstract}
Glacial and lacustrine sediments from the Mongolian Altai provide paleoclimatic information for the late Pleistocene in Mongolia, for which only a few sufficiently studied archives exist. Glacial stages referred to global cooling events are reported for the last glacial maximum (27-21 ka) and the late glacial period (18-16 ka). Sedimentary archives from the first part of the last glacial period are infrequent. We present proxy data for this period from two different archives (88-63 and 57-30 ka). Due to the limitation of effective moisture, an increase of precipitation is discussed as one trigger for glacier development in the coldarid regions of central Asia. Our pollen analysis from periods of high paleolake levels in small catchments indicate that the vegetation was sparse and of dry desert type between 42-29 and 17-11 ka. This apparent contradiction between high lake levels and dry landscape conditions, the latter supported by intensified eolian processes, points to lower temperatures and cooler conditions causing reduced evaporation to be the main trigger for the high lake levels during glacier advances. Rising temperatures that cause melting of glacier and permafrost ice and geomorphological processes play a role in paleolake conditions. Interpreting lake-level changes as regional or global paleoclimate signals requires detailed investigation of geomorphological settings and mountain-basin relationships.
\end{abstract}

Keywords: Mongolia; Paleoclimate; Palynology; Glaciation; Paleolakes

\section{INTRODUCTION}

The Altai Mountains are located in the northern part of central Asia within the territories of Russia, Mongolia, China, and Kazakhstan. The Altai Mountains consist from northwest to southeast of the Russian, the Mongolian, the Chinese, and the Gobi Altai. Two main circulation systems are controlling the climate conditions here at the border between the coldhumid Siberian taiga in the north and the arid Gobi Desert in the south (Wesche et al., 2016). In the summer, the

Cite this article: Klinge, M., Schlütz, F., Zander, A., Hülle, D., Batkhishig, O., Lehmkuhl, F. 2021. Late Pleistocene lake level, glaciation and climate change in the Mongolian Altai deduced from sedimentological and palynological archives. Quaternary Research 99, 168-189. https:// doi.org/10.1017/qua.2020.67 cyclonic circulation system delivers wet air masses via the westerlies from the Atlantic Ocean, producing most of the annual precipitation. A dry season starts in autumn. During the winter, the Siberian high-pressure cell persists over Siberia and Mongolia, driving cold and dry Artic air masses into the region that induce dry climate and minor snowfall (Böhner, 2006). The position, the seasonal movement, and the intensity of these two Northern Hemisphere climatic systems are responsible for the distribution of regional effective moisture conditions (Herzschuh, 2006; Rudaya et al., 2009). The vegetation pattern, the mountain glaciation, and the endorheic lake levels reflect the local conditions of effective moisture in the semihumid to arid regions of Mongolia. A shift in these landscape elements documents climate changes (Klinge and Sauer, 2019). The western part of the (Russian) Altai 
Mountains receives high precipitation via the westerlies and has humid conditions in summer. In contrast, the eastern part of the Mongolian Altai is situated in the rain shadow and is arid (Klinge et al., 2003; Rudaya et al., 2009). The study area is one of the most continental regions on Earth, having a high annual range of temperatures and low precipitation. Internal drainage exists, and the main rivers run into the terminal lakes of the large basin in the east of the Altai Mountains, called the "Valley of Great Lakes." Due to this endorheic drainage, mountain glaciation and terminal-lake levels are closely linked and are suitable indicators of local and regional climate development (Gunin et al., 1999; Grunert et al., 2000; Peck et al., 2002; Fowell et al., 2003; Lehmkuhl et al., 2016, 2018; Blomdin et al., 2018; Klinge and Sauer, 2019).

The spatial extension of recent and past glaciations can be mapped by fieldwork, satellite images, aerial photos, and topographic maps (Klinge, 2001; Blomdin et al., 2014; Kamp et al., 2013a; 2013b). The modern glaciation in the Altai Mountains is restricted to the highest peaks in the centers of mountain massifs and consists of plateau glaciers and ice caps with triangular glacial tongues, cirque glaciers, and small valley glaciers. On the basis of satellite images, Yabuki and Ohata (2009) have identified a total of 578 Mongolian glaciers covering an area of $423 \mathrm{~km}^{2}$. The glaciated area decreases to the southeast, while the climatic snowline increases from $2600 \mathrm{~m}$ above sea level (asl) in the western Russian Altai to $3700 \mathrm{~m}$ asl in the southeastern Mongolian Altai (Klinge, 2001; Klinge et al., 2003; Lehmkuhl, 2012). Former glaciations are determined and distinguished by glacial deposits and erosion landforms (Grunert et al., 2000; Klinge, 2001; Lehmkuhl et al., 2004, 2011; Blomdin et al., 2014; Ganyushkin et al., 2018). Glacial deposits are represented by till and sediments from different types of moraines. Cirques, U-shaped valleys, and small lakes in depressions formed by glacial confluence and erosion indicate landforms of glacial erosion. Several mountain glaciations with large valley glaciers, which partly stretched into the basins, occurred in the westernmost part of the Mongolian Altai during the Pleistocene. In contrast, most of the Pleistocene glaciation in western Mongolia was limited due to the precipitation reduction from west to east. Both Pleistocene and present-day climatic snowlines have a rising gradient toward the east. According to Lehmkuhl et al. (2011), the gradient of the snowlines toward arid regions was steeper during glacial times. Snowline depressions during the Pleistocene glaciations were more than $1000 \mathrm{~m}$ in the wettest parts of the western Russian Altai but only 800 to $400 \mathrm{~m}$ in the eastern part of the Russian Altai and in the Mongolian Altai, respectively (Lehmkuhl et al., 2011).

It is commonly accepted that the two maximum glacial stages in western Mongolia are clearly distinguished by the distribution of well-defined groups of moraine ridges (Klinge, 2001; Lehmkuhl et al., 2004, 2016). In front of the terminal moraines of these stages, remnants of a third moraine unit, which are strongly denuded, can be identified occasionally as the maximum stage of an older glacial period. These moraines were classified by geomorphological evidence, such as weathering criteria and connection to glaciofluvial terraces, as $\mathrm{M}_{0}$ and $\mathrm{M}_{1 \mathrm{a} / \mathrm{b}}$ for the last glacial period (MIS 5d-2) and as $\mathrm{M}_{2}$ for the penultimate glaciation (Grunert et al., 2000; Lehmkuhl et al., 2004). While the maximum extension of the late Pleistocene glaciation is widely identified, the exact timing of the local last glacial maximum (ILGM) is still a matter of debate. The first classifications of the glacial stages were based on morphostratigraphic correlations to the Siberian glacial system (Arkhipov et al., 1986; Grunert et al., 2000; Lehmkuhl et al., 2004). Two main glacial stages $\left(\mathrm{M}_{1 \mathrm{a} / \mathrm{b}}\right)$ were correlated to the Sartan and early Zyrianka glaciations, which correspond to MIS 2 and 4 , respectively. The older $\mathrm{M}_{2}$ was assigned to the Taz or Somarova glaciations of mid-Pleistocene age, whereas late glacial stages were assigned to $\mathrm{M}_{0}$ (Lehmkuhl et al., 2004). Since the 1990 s, radiometric dating by ${ }^{14} \mathrm{C}$ analysis and the luminescence method were used to determine the numerical ages for the glacial deposits (Lehmkuhl and Lang, 2001; Lehmkuhl et al., 2011, 2016; Ganyushkin et al., 2018). Organic matter from paleosols, wood, and peat can be dated with the first method, eolian and occasionally fluvial and lacustrine sediments with the latter. However, these methods are not suitable for direct examination of the glacial till, because the development of organic material and the total bleaching of grains seldom occur simultaneously with its deposition. The ages provide just a temporal framework, but may not reflect the accurate age for the deposition of a moraine or the timing of the corresponding glacial period. The ${ }^{10} \mathrm{Be}$ surface-exposure dating method (cosmogenic radionuclide) represents a valuable tool to determine the ages of erratic boulders placed upon the moraines and the baring of roche moutonées. However, the morphological history of a boulder transported, deposited, and retransported by glacial and periglacial processes does not lead to a total resetting of the radiometric clock in every case. Thus, several samples from one moraine are necessary to detect outliers from the central time range (Heyman et al., 2011).

A review of the state of investigations about dating of glacial moraines in Mongolia has been published by Khandsuren et al. (2019). To summarize, the MIS 2 glaciation was the most explicit stage of the last glacial period found in every mountain region of Mongolia, whereas the timing of a previous stage varies among MIS 3, 4, and late 5. A late glacial stage was widespread in the Mongolian mountains and is generally reported for the period between 18 and $15 \mathrm{ka}$ in the beginning of the late-glacial period (LGP; 18-11.5 ka). The MIS 3 glacial advance was attributed to a wet phase under cool climate conditions, whereas the MIS 2 glacial stage represents the coldest and dry period of the last glaciation (Rother et al., 2014; Batbaatar et al., 2018; Khandsuren et al., 2019). The temperature generally increased after the LGM (MIS 2; Clark et al., 2009), and the last distinct glacial advance occurred during a global cooling event around $16 \mathrm{ka}$ (Khandsuren et al., 2019). However, Batbaatar et al. (2018) provided evidence, based on glacial advances during wet climate periods in the Holocene, that regional glaciation is not only controlled by coldness but also by higher precipitation and seasonality of temperature. 
Higher paleolake levels, often interpreted as periods of increased effective moisture, were reported in a local context in the Mongolian Altai for different periods in the late Pleistocene (Devyatkin, 1981; Naumann, 1999; Walther, 1999; Grunert et al., 2000; Klinge and Lehmkuhl, 2013). Although there are several systems of beach walls and strandlines detectable around the terminal lakes in western Mongolia, radiometric dating of these landscape elements is rare. High lake levels were reported for the Uvs Nuur basin (nuur means "lake" in the Mongolian language) (Fig. 1) in the LGP between 13 and 11 $\mathrm{ka}$, whereas very low lake levels or desiccation occurred at the end of LGM in the transition to the LGP (20-16 ka) (Grunert et al., 2000). Based on these findings and concordant with other research in the region, Grunert et al. (2000) assumed a wet-cold period between 32 and 25 ka during glacial build up (anaglacial phase), and a dry-cold period between 24-15 ka of the LGM, when the glaciers persisted at their maximum extensions (kataglacial phase) (Hövermann, 1998; Lehmkuhl and Haselein, 2000). The low lake level of Uvs Nuur during the LGM was induced by dry conditions, whereas meltwater and increased precipitation led to rising lake levels at the end of the LGP. For the Achit Nuur basin (Fig. 1), which drains into the Valley of Great Lakes via the Khovd Gol ( $g o l$ means "river" in the Mongolian language), Agatova and Nepop (2019) hypothesized episodically high lake levels induced by cataclysmic outburst floods from glacier- and moraine-dammed lakes in the Mogen-Buren depression in the north before $11 \mathrm{ka}$.

In particular, changing climate influences the growing conditions and density of the vegetation cover in the semiarid regions. Increasing precipitation leads to a higher density of steppe vegetation, whereas the effect of cool temperature on the vegetation cover is more differentiated. Cool summers may reduce the occurrence of drought events, but they also may reduce the growing season due to a decrease in frost-free days. Pollen records from different archives provide information on past vegetation distribution and paleo-environmental conditions. Most of the pollen records from the Mongolian Altai and western Mongolia are of Holocene age (Gunin et al., 1999; Fowell et al., 2003; Rudaya et al., 2009; Unkelbach et al., 2017, 2019). Pollen records from periods older than the MIS 2 (LGM) are exclusively reported by Ma et al. (2013). Pollen records from lake sediments were investigated by Sun et al. (2013) from the Achit Nuur, reaching back until $22.6 \mathrm{ka}$, and by Tian et al. (2014) from the Bayan Nuur, starting around 15.6 ka. At Khoton Nuur (Fig. 1), a glacial lake impounded by a terminal moraine upstream of the Khurgan Nuur, Rudaya et al. (2009) and Rudaya and Li (2013) analyzed pollen, diatoms, and organic elements. The authors inferred a cold and dry LGP before $11.5 \mathrm{ka}$, based on pollen spectra indicating dry steppe vegetation and diatoms pointing to cold lake water. Thereafter, the climate changed to warm and humid during the early Holocene. Eolian sediments, reported for the LGP from various sites in the Altai Mountains (Grunert et al., 2000; Feng, 2001; Peck et al., 2002; Feng et al., 2007; Yang et al., 2006) are commonly regarded as indicators for enhanced dust transport under dry conditions. Increasing intensity of wind gustiness (Roe, 2009) may also amplify eolian transport. In addition, high dust supply from silty sediments, which are exposed to deflation due to retreating glaciers and desiccating lakes, may cause enhanced eolian deposition.

The often contradicting evidence from glacial advances, lake stands, vegetation changes, and climate reconstructions for the late Pleistocene make analysis of specific local driver(s) behind environmental changes challenging. As described earlier, common agreement for a cold and dry climate during the LGM around 20 ka exists, but the climate reconstructions before (MIS 3) and after (LGP) are still a matter of debate. Against this regional background, we present new data for lake and vegetation development derived from small catchments in the Mongolian Altai during these periods. We hypothesize that increased effective moisture led to the glacial expansion in the initial phase (anaglacial) starting at the end of MIS 3, with glaciers persisting during the cold and dry LGM, whereas rising temperature and evaporation induced the rapid depletion of glaciers and melting of permafrost during the late phase (kataglacial) in the second half of the LGP. We discuss our findings with regard to existing paleo-data to decipher the complex interconnections among lakes, vegetation, glaciers, and climate.

\section{STUDY AREA}

The Mongolian Altai is located in western Mongolia and consists of separated mountain massifs, reaching up to more than $4000 \mathrm{~m}$ asl. The Khovd Gol drains the northwestern part of the Mongolian Altai into the Valley of Great Lakes. The great lakes Khar Us Nuur, Khar Nuur, and Khyargas Nuur are distributed in this endorheic basin to the east of the Mongolian Altai. The northernmost part belongs to the catchment of the Uvs Nuur basin. Furthermore, several closed basins with small catchments occur due to the arid climate in the lee of the Russian Altai and tectonic activity. The climate in the region is highly continental, varying between semiarid in the mountains and arid to hyperarid in the basins. The mean annual air temperature ranges between $-11^{\circ} \mathrm{C}$ in the mountains and $3{ }^{\circ} \mathrm{C}$ in the basins, and large annual amplitudes between 45 and $60 \mathrm{~K}$ of mean monthly air temperatures exist (Karger et al., 2017). In winter, the Siberian highpressure cell results in cold and dry conditions with mean air temperatures between $-15^{\circ} \mathrm{C}$ and $-35^{\circ} \mathrm{C}$, with extreme temperatures of $-56^{\circ} \mathrm{C}$ in the Uvs Nuur depression (Barthel, 1983; Batima et al., 2005). The main precipitation derives from cyclones and occurs when the westerlies carry humid air masses along the Siberian lowlands. Thus, about $85 \%$ of the precipitation occurs in summer between April to September. The growing season ends with a dry period in autumn. The winter is mostly dry with little snowfall (Lehmkuhl and Klinge, 2000). The mean annual precipitation in the Mongolian Altai is more than $500 \mathrm{~mm}$ in the high mountains and less than $50 \mathrm{~mm}$ in the interior basins (Barthel, 1983; Batima et al., 2005; Böhner, 2006; Karger et al., 2017). The basins and valleys are covered by steppe and desertsteppe vegetation. In some parts of the mountains, a lower 


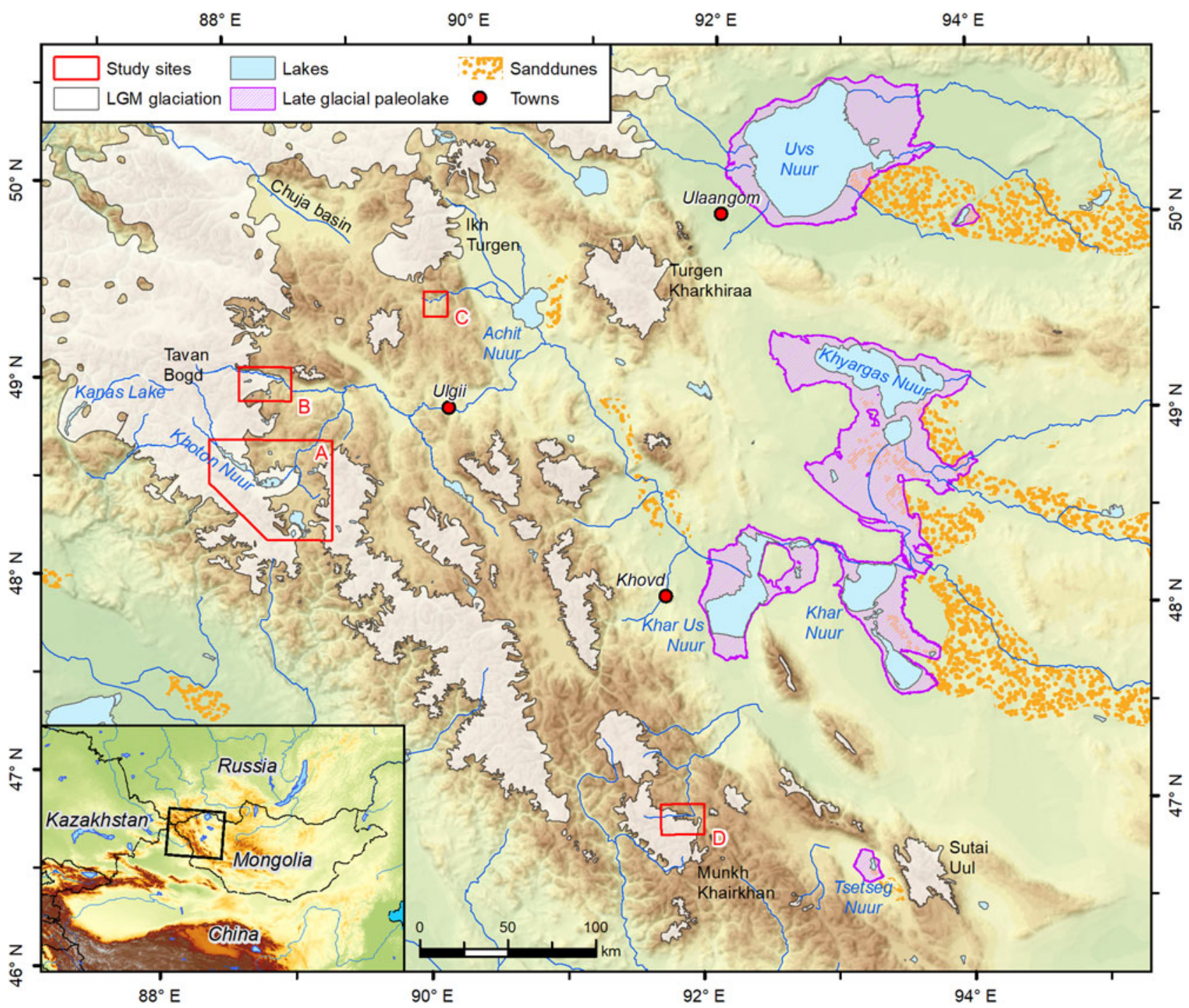

Figure 1. (color online) Areas of investigation in the Mongolian Altai. The map shows the glaciated area during the late Pleistocene and the expansion of high lake levels during the late glacial period. (SRTM digital elevation model 90m, Projection UTM Zone 46 North). (A) Khoton Nuur and Khurgan Nuur; (B) Tsagaan Gol; (C) Ekhen Nuur; (D) Munkh Khairkhan. Box in the inset map indicates the extent of the main map. LGM, last glacial maximum.

vegetation belt of forest steppe exists. In the forest-steppe ecotone, forests of mostly Larix sibirica occur on northfacing slopes, whereas mountain steppe covers south-facing slopes (Schlütz et al., 2008). In the high mountains, an alpine belt with dense shrub vegetation and meadows leads to the periglacial zone of frost debris. Along the rivers, dense meadows and trees like poplar, willow, and larch occur (Hilbig, 1995).

The detailed investigations focus on four study sites (Fig. 1, sites A-D). Two sites are located at large glacial terminal moraine complexes in the western Mongolian Altai connected to the highest Mongolian peak, Tavan Bogd (4374 m asl). The Khoton Nuur (Fig. 2, site A1) and Khurgan Nuur (Fig. 2, sites A2 and A3) terminal moraines lie in a wide intermountain basin drained by the Khovd Gol. Study site B is situated in front of a terminal moraine near the tectonic valley of the Tsagaan Gol. The Ekhen Nuur (site C) lies in a small intermountain basin. The high-altitude site Munkh
Khairkhan (site D) is located in the southern part of the Mongolian Altai, with the investigated lake dammed in a closed basin by a lateral moraine.

The palynological analyses were done at sites $\mathrm{C}$ and $\mathrm{D}$. The landscape around the Ekhen Nuur (site C; $2115 \mathrm{~m}$ asl) is dominated by steppes rich in Poaceae (Agropyron cristatum, Stipa krylovii, etc.) accompanied by Caryophyllaceae (Arenaria meyeri, A. capillaris, Silene repens), Potentilla sericea, Artemisia frigida, and other Asteraceae, Apiaceae, and Lamiaceae. The vegetation of the desert steppes (semideserts) to the east in the Achit Nuur basin consists of Stipa glareosa, Stipa gobica, several Chenopodiaceae (Anabasis brevifolia, Eurotia ceratoides, Chenopodium frutescens), Artemisia xerophytica, and other Asteraceae (Ajania, Asterothamnus). The Munkh Khairkhan site (site D) (2730 m asl) is situated near the upper border of the mountain steppe with a variety of Poaceae that grades to alpine vegetation rich in Cyperaceae like Kobresia humilis and 




Figure 2. Glacial morphology and sampling sites at Khoton Nuur (A1) and Khurgan Nuur (A2, A3). New luminescence ages (in ka $\pm 1 \sigma$ error) are indicated by yellow dots. The drilling sites of (1) Gunin et al. (1999), (2) Rudaya et al. (2009) and Rudaya and Li (2013), and (3) Unkelbach et al. $(2017,2019)$ are indicated by green dots. The background Landsat 8 satellite image was recorded on August 31, 2014. (For interpretation of the references to color in this figure legend, the reader is referred to the web version of this article.)

Carex rupestris. The endemic Caryophyllaceae Stellaria pulvinata grows between 2600 and $3300 \mathrm{~m}$ asl, and Potentilla nivea is found from the mountain steppes up to about $3000 \mathrm{~m}$ asl (Bocharnikov et al., 2015). The very restricted forests of the Mongolian Altai are dominated by Siberian larch (L. sibirica). The forest belt has a small vertical extension $(400-0 \mathrm{~m})$ between its lower boundary at $2000-2400 \mathrm{~m}$ asl and the upper treeline at about $2400-2600 \mathrm{~m}$ asl (Klinge et al., 2018). The closest modern occurrences of $L$. sibirica to the palynological sites are open stands with isolated trees that are at least $20 \mathrm{~km}$ away. Siberian spruce (Picea obovata) and Siberian pine (Pinus sibirica) grow at a very few sites in the northwestern part of the mountain range near to the borders with China and Russia. Dark taiga with Siberian fir (Abies sibirica) is restricted today to the Khentei Mountains in northeastern
Mongolia (Dulamsuren et al., 2005; Grubov, 2011). The nearest stands of A. sibirica to the study sites lie to the north in the Russian taiga. Based on dated charcoals, spruce but also fir were growing together with larch in the southern part of the Mongolian Altai around $4000 \mathrm{yr}$ BP (Dinesman et al., 1989), and at least larch even reached the Gobi Altai during the wetter middle Holocene (Miehe et al., 2007).

\section{METHODS}

\section{Fieldwork and mapping}

Sediment profiles at several terminal lakes with small catchment areas were examined and sampled for pollen analysis and radiocarbon and luminescence dating during fieldwork 
Table 1. Description of sediment profiles.

\begin{tabular}{lclll}
\hline \hline Site & No. & Site name & Location, elevation above sea level & \multicolumn{1}{c}{ Sediment type } \\
\hline A & 1 & Khoton Nuur & $48^{\circ} 35.9^{\prime} \mathrm{N} 88^{\circ} 25.5^{\prime} \mathrm{E}, 2091 \mathrm{~m}$ & Eolian layer in terminal moraine \\
A & 2 & Khurgan Nuur & $48^{\circ} 36.4^{\prime} \mathrm{N} 88^{\circ} 45.7^{\prime} \mathrm{N}, 2052 \mathrm{~m}$ & Glaciolacustrine sediments in terminal moraine \\
A & 3 & & & \\
B & 4 & Tsagaan Gol 1 & $49^{\circ} 00.9^{\prime} \mathrm{N} 88^{\circ} 31.9^{\prime} \mathrm{E}, 2419 \mathrm{~m}$ & Glaciolacustrine sediments upon terminal moraine \\
B & 5 & Tsagaan Gol 2 & & \\
C & 6 & Ekhen Nuur & $49^{\circ} 29.5^{\prime} \mathrm{N} 89^{\circ} 45.1^{\prime} \mathrm{E}, 2100 \mathrm{~m}$ & Eolian silt-lacustrine clay, alternating with layers rich in plant remains \\
D & 7 & Munkh Khairkhan & $46^{\circ} 57.1^{\prime} \mathrm{N} 91^{\circ} 41.0^{\prime} \mathrm{E}, 2730 \mathrm{~m}$ & $\begin{array}{c}\text { Eolian-lacustrine silt and clay alternating with layers rich in } \\
\text { plant remains }\end{array}$ \\
\hline \hline
\end{tabular}

in western Mongolia (Fig. 1, Table 1). The geomorphological maps illustrating the stratigraphic positions of the investigation sites were compiled from field mapping, Landsat 8 satellite images, and the SRTM digital elevation model.

\section{${ }^{14} \mathrm{C}$ dating}

Radiocarbon dates on sampled plant remains were determined by the conventional ${ }^{14} \mathrm{C}$ method at the laboratory of the Joint Geoscientific Research Institute in Hanover, Germany (Table 2). The radiocarbon ages are calibrated with the Calib Rev 7.0.4 Software (Stuiver and Reimer, 1993) using the IntCal13 data set (Reimer et al., 2013) and presented in cal ka BP in the text.

\section{Luminescence dating}

Optically stimulated luminescence (OSL) and infrared stimulated luminescence (IRSL) dating was applied on five samples from five sections to determine the timing of deposition. Quartz has been shown to bleach much faster than potassium feldspar (Colarossi et al., 2015; Thomsen et al., 2008) and is therefore often preferred for luminescence dating. Unfortunately sand-sized quartz from Mongolia is often conjoined with feldspar inclusions, which usually compromises the reliability of quartz OSL dating (Hülle et al., 2010; Lehmkuhl et al., 2016). The majority of luminescence dating studies from Mongolia therefore focus on sand-sized potassium feldspar, but the lacustrine sediments of this study do not contain any sand-sized minerals. Therefore, 4-11 $\mu \mathrm{m}$ polymineral and quartz fractions were used for dating. The standard chemical treatment for sample preparation was applied, and the 4-11 $\mu \mathrm{m}$ fraction was extracted by means of a centrifuge (Frechen et al., 1996). To extract pure quartz from these polymineral sample extracts, about half of the mass was etched for 7 days in $34 \% \mathrm{H}_{2} \mathrm{SiF}_{6}$. The other half was not further treated. The samples were pipetted from a suspension of demineralized water $(1.0 \mathrm{mg} / \mathrm{ml})$ on stainlesssteel discs.

All measurements were carried out on an automated Ris $\varnothing$ TL/OSL reader (TL-DA-20) equipped with a ${ }^{90} \mathrm{Sr} /{ }^{90} \mathrm{Y}$ B-source for irradiation and a EMI9235 photomultiplier tube for luminescence detection (Bøtter-Jensen et al., 2003). Infrared (IR; $870 \Delta 80 \mathrm{~nm})$ and blue $(470 \Delta 20 \mathrm{~nm})$ LEDs were used for stimulation, and the signal was detected through a D410 LOT Oriel interference filter (IRSL) and a Hoya U340 filter (OSL). Two different protocols were applied for equivalent dose $\left(\mathrm{D}_{\mathrm{e}}\right)$ determinations of the polymineral fine-grain fraction: (1) a standard IRSL protocol $\left(\mathrm{IR}_{50}\right)$ with a low-temperature $\mathrm{IR}$ measurement at $50^{\circ} \mathrm{C}$ after a preheat of $250^{\circ} \mathrm{C}$; and (2) an elevated temperature post-IR-IRSL ( IRIR $_{290}$ ) single-aliquot regenerative-dose (SAR) protocol (Buylaert et al., 2009) with a pIR measurement at $290^{\circ} \mathrm{C}$ after a first IR measurement at $50^{\circ} \mathrm{C}$ and a

Table 2. Results of ${ }^{14} \mathrm{C}$ dating.

\begin{tabular}{llccccc}
\hline \hline Lab. no. & Site no. & $\begin{array}{c}\text { Sample depth } \\
(\mathrm{cm})\end{array}$ & $\begin{array}{c}\text { Conventional } \\
14\end{array}$ C age $(\mathrm{BP} \pm 1 \sigma)$ & $\begin{array}{c}\text { Calibrated age }(1 \sigma) \\
(\text { cal yr BP })\end{array}$ & $\begin{array}{c}\text { Calibrated age }(2 \sigma) \\
(\text { cal yr BP })\end{array}$ & $\begin{array}{c}\text { Calibrated median age } \\
(\mathrm{cal} \mathrm{ka} \mathrm{BP})\end{array}$ \\
\hline Hv23288 & D 7.1 & $0-10$ & $25,330 \pm 240$ & $29,056-29,681$ & $28,815-30,127$ & 29.47 \\
Hv23289 & D 7.2 & $180-190$ & $28,900 \pm 345$ & $32,632-33,553$ & $31,931-33,776$ & 32.86 \\
Hv23290 & D 7.3 & $255-270$ & $24,150 \pm 265$ & $27,913-28,451$ & $27,734-28,702$ & 28.22 \\
Hv23291 & D 7.4 & $370-375$ & $37,530 \pm 1,080$ & $40,991-42,699$ & $39,767-43,436$ & 41.60 \\
Hv23292 & D 7.5 & $410-412$ & $25,465 \pm 430$ & $29,076-30,168$ & $28,702-30,651$ & 29.68 \\
Hv23297 & C 6.1 & $78-80$ & $9490 \pm 60$ & $10,655-10,794$ & $10,579-10,882$ & 10.73 \\
Hv23296 & C 6.2 & $260-262$ & $10,175 \pm 90$ & $11,699-12,041$ & $11,392-12,163$ & 11.78 \\
Hv23295 & C 6.3 & $375-380$ & $10,130 \pm 90$ & $11,604-11,988$ & $11,340-12,076$ & 11.71 \\
Hv23294 & C 6.4 & $619-622$ & $10,320 \pm 75$ & $12,012-12,240$ & $11,823-12,417$ & 12.12 \\
Hv23293 & C 6.5 & $677-680$ & $14,465 \pm 95$ & $17,495-17,770$ & $17,368-17,912$ & 17.64 \\
\hline \hline
\end{tabular}


preheat at $320^{\circ} \mathrm{C}$ (Thiel et al., 2011) for samples where the standard $\mathrm{IR}_{50}$ protocol failed to recover a given dose. The stimulation at elevated temperatures also minimizes the effect of anomalous fading (Wintle, 1973), which can cause age underestimation. To check for this interfering signal loss, specific fading tests were carried out according to Huntley and Lamothe (2001) and used to correct the $\mathrm{IR}_{50}$ ages for fading. A preheat plateau protocol with SAR-OSL measurements at $125^{\circ} \mathrm{C}$ (Murray and Wintle, 2000) and preheat temperatures between 200 and $240^{\circ} \mathrm{C}$ was applied to the according finegrained quartz samples (C-L3596, C-L3598, C-L3599). With regard to the better bleaching properties of quartz, a comparison between quartz OSL and pIRIR 290 measurements can give information about the reliability of the polymineral finegrain data. IR-depletion ratios (Duller, 2003) within 10\% unity were determined for all fine-grained quartz samples (Table 3). Acceptance criteria for $D_{e}$ determination were set to $10 \%$ for recycling ratios, recuperation, and test-dose uncertainties, and the central age model (Galbraith et al., 1999) was used for the final $D_{e}$ determination. Environmental dose rates are based on laboratory high-resolution gamma-spectrometry measurements using $\sim 400 \mathrm{~g}$ of bulk homogenized material. The software DRAC v1.2 (Durcan et al., 2015) was applied for dose-rate and age calculation. Natural water content was calculated relative to the dry mass following Nelson and Rittenour (2015), and the cosmic dose-rate contribution was evaluated following Prescott and Hutton (1994). An internal potassium content of $12.5 \pm 0.5 \%$ (Huntley and Baril, 1997) was assumed.

\section{Pollen analysis}

Palynological results are presented from two natural cliff profiles eroded into sediments of former lake high stands that consist of clays, silts, and carbonates. In the $6.5-\mathrm{m}$-high cliff of the Ekhen Nuur (Fig. 1, site C), samples were taken from sections exhibiting plant material. The Munkh Khairkhan cliff (Fig. 1, site D) was sampled from $2 \mathrm{~m}$ to $6.2 \mathrm{~m}$ depth. During the preparation for palynological analyses, a few grams of sediment per sample were treated with hydrochloric acid, potassium hydroxide, hydrofluoric acid, and acetolysis mixture (acetic anhydride with sulfuric acid, 10:1), then microsieved $(6 \mu \mathrm{m})$ and stored in glycerol. A total of at least 330 terrestrial pollen grains were identified for each sample, except one. The pollen identification is based on the literature (Wang et al., 1995) and a collection of about 5000 type slides. The standard magnification was 500x, whereas ambiguous objects were viewed at $1250 \times$ with oil immersion. All presented finds of pollen grains, spores, and algae are calculated as percentages of the sums of the terrestrial pollen grains. Plotting was done with C2 software (Juggins, 2007). Morphological pollen and spore types were inferred from Beug (2015) and Moore et al. (1991) with taxonomic adaptation to the Mongolian flora (Grubov, 2011). Plant families in the text and diagrams do not include separated types; for instance, Chenopodiaceae does not include counts of the Haloxylon-type and Poaceae does not include the Cerealia-type.

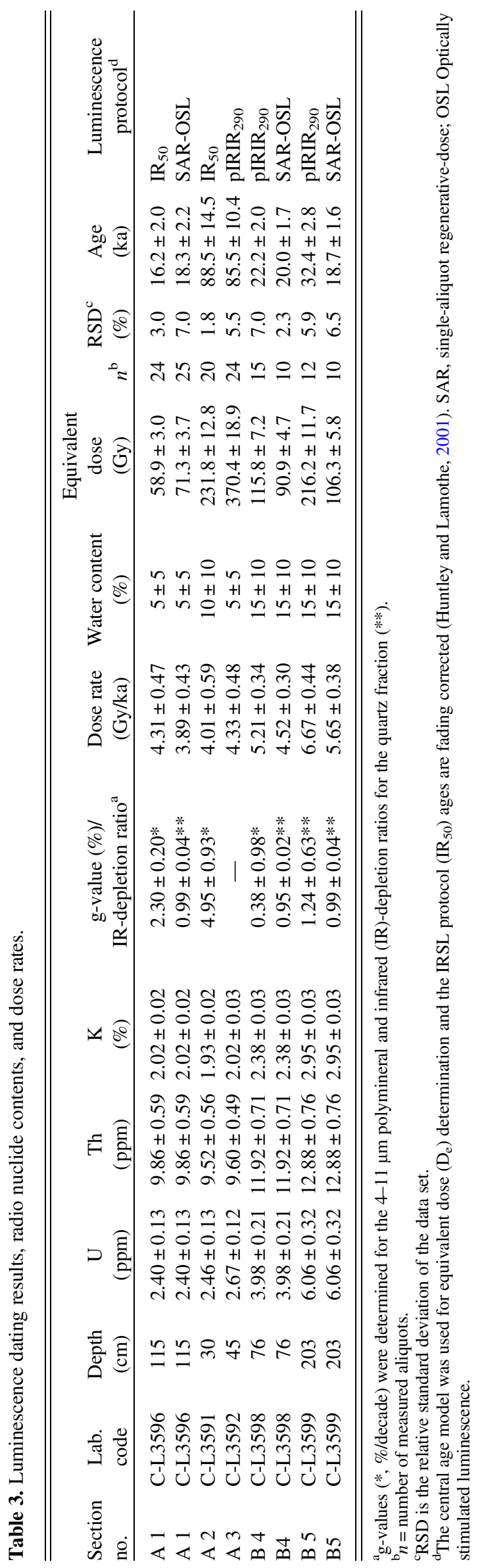




\section{RESULTS}

\section{Geomorphological findings}

\section{Khoton Nuur and Khurgan Nuur (site A)}

The geomorphological settings and the sediment sections at the Khurgan Nuur and Khoton Nuur $\left(48^{\circ} 36^{\prime} \mathrm{N}, 88^{\circ} 45^{\prime} \mathrm{E}\right.$, $2050 \mathrm{~m}$ asl; Fig. 2) were described by Lehmkuhl et al. (2016). In addition, new fading-corrected luminescence ages provide additional numerical dating for these findings. Both lakes are impounded by terminal moraines, which were formed by a large Pleistocene valley glacier flowing from the Tavan Bogd peak (4374 m asl) in a southeasterly direction. Voluminous morainic sediments of an extensive ice-marginal zone cover an intermountain tectonic basin and create a hummocky terrain around the Khurgan Nuur. These sediments incorporate large amounts of laminated glaciolacustrine clay and silt, which provide evidence for a proglacial lake. This paleolake must have existed during the late Pleistocene ice advances and glacial oscillations. Samples A2 and A3 were taken from a section in laminated lacustrine sediments, which are exposed within the outer moraine $\mathrm{M}_{1 \mathrm{c}}$ (Fig. 3c). These lake sediments show micro-fault structures and are likely to have been transported en bloc, possibly as a frozen slab, and merged into the till. IR $_{50}$ and pIRIR dating of these sediments yielded fading-corrected ages of $88.5 \pm$ 14.5 (silt) and $85.5 \pm 10.4 \mathrm{ka}$ (clay) (Table 3). These ages are strong evidence for the timing of the development of the proglacial lake during brief retreats and readvances of moraine $\mathrm{M}_{1 \mathrm{c}}$ at Khurgan Nuur between the late MIS 5 and MIS 4 in an early state of the last glacial period.

The Khoton Nuur lies a few kilometers upstream of Khurgan Nuur and is dammed by a terminal moraine $\mathrm{M}_{1 \mathrm{a}}$. Profile A1 is located at a section where the river cuts a 13-m-deep channel across the terminal moraine (Fig. 3a). A layer of eolian silt and sand (Table 1, A1) occurs in between the till, $1.2 \mathrm{~m}$ below the surface. A sample from this layer was dated by $\mathrm{IR}_{50}$ and OSL and provided ages of $16.2 \pm 2.0$ (fading corrected) and $18.3 \pm 2.2 \mathrm{ka}$ (Table 3, A1). This dating demonstrates that the $\mathrm{M}_{1 \mathrm{a}}$ moraine formed during the LGP, while the $\mathrm{M}_{1 \mathrm{~b}}$ moraine was deposited during or before MIS 2. After the LGP, the glacier retreated, and the lake developed before 11.5 $\mathrm{ka}$, as inferred by the sediment record of Rudaya et al. (2009).

\section{Tsagaan Gol (site B)}

The Tsagaan Gol runs from the Potanin glacier at the Tavan Bogd peak eastward into the Khovd Gol. The terminal moraine of the main valley $\left(49^{\circ} 01^{\prime} \mathrm{N}, 88^{\circ} 32^{\prime} \mathrm{E}, 2420 \mathrm{~m}\right.$ asl; Fig. 4) merges with terminal moraines from two southern side valleys. The terminal moraine blocks up a side valley and creates a closed basin with the investigated saline terminal lake. The lacustrine pebbles at the beach ridges are covered by a white crust. The various beach ridges and strandlines below and up to $20 \mathrm{~m}$ above the present lake level $(2310 \mathrm{~m}$ asl $)$ were created by an oscillating lake level during an overall decreasing phase. Furthermore, the highest lake level ( $70 \mathrm{~m}$ above the recent level) is indicated by a distinct cliff in the surrounding mountains (Fig. 3c). In the northern part of the closed basin, a depression in the crest line, which is at the same altitude as the cliff, represents the former overflow of the paleolake (Fig. 4). The gentle slope at this spillway indicates that the outflow of this paleolake was not strong and minimal erosion occurred. Laminated lacustrine sediments of clay and silt lie upon the exterior side of the terminal moraine $\mathrm{M}_{1 \mathrm{c}}$, (Fig. 3d). The sediment package of more than $4 \mathrm{~m}$ shows softly deformed layers. A nearly frozen soil at the bottom of the sections indicates the recent occurrence of permafrost. These lacustrine sediments have the same altitude as the cliff and therefore correspond to the highest lake level. Samples for luminescence dating were taken from the bottom of the lacustrine sediments at two different sections (Table 1, B) and provided ages between $32.4 \pm 2.8$ and $22.2 \pm 2.0 \mathrm{ka}$ for pIRIR and between $20.0 \pm 1.7$ and $18.7 \pm 1.6 \mathrm{ka}$ for SAROSL (Table 3, B4 and B5). Three of the four ages are in perfect agreement within $1 \sigma$ error, but the pIRIR age of C-L3599 is overestimated, which implies partial bleaching for the lower sediments. These results date the high lake level into the initial phase of the LGM (MIS 2) and indicate a minimum age of the outer moraine complex $\mathrm{M}_{1 \mathrm{c}}$.

\section{Ekhen Nuur (site C)}

The Ekhen Nuur is located in a tectonic depression near the settlement Tsagaannuur $\left(49^{\circ} 30^{\prime} \mathrm{N}, 89^{\circ} 45^{\prime} \mathrm{E}, 2100 \mathrm{~m}\right.$ asl; Fig. 5) in the northwestern part of the Mongolian Altai. Several small lakes are drained via the Khavtsaliin Gol eastward into the Achit Nuur basin. As indicated by strandlines about $6.5 \mathrm{~m}$ above the recent lake level, these lakes were formerly joined to a common large lake. Up to 6.8-m-thick lacustrine sediments with many layers of 0.5 to $1 \mathrm{~cm}$ thickness containing plant remains separate the Ekhen Nuur from the neighboring lakes (Fig. 3e). We sampled the peat layers systematically for pollen analysis and ${ }^{14} \mathrm{C}$ dating (Table $1, \mathrm{C}$ ). Permafrost ice was found at a depth of $6.4 \mathrm{~m}$ below the sediment surface. The ${ }^{14} \mathrm{C}$ dating provided consistent ages, which showed that the upper $6 \mathrm{~m}$ developed between 12.4 and $10.6 \mathrm{cal} \mathrm{ka}$ $\mathrm{BP}$, whereas the base of the exposed section has an age of $\sim 17.9$ cal ka BP (Table 2, C6). These results evidence a late glacial paleolake and put the high lake level into the transition period from the LGP to the early Holocene, when a high input of eolian sediments also occurred (Grunert et al., 2000; Grunert and Lehmkuhl, 2004; Klinge et al., 2017).

\section{Munkh Khairkhan (site D)}

The geomorphological evidence from the glacial terminal moraines at the eastern side of Munkh Khairkhan $\left(46^{\circ} 57^{\prime} \mathrm{N}\right.$, $91^{\circ} 41^{\prime} \mathrm{E}, 2730 \mathrm{~m}$ asl; Fig. 6) were described by Klinge (2001) and Lehmkuhl et al. (2004). Here, a side valley was dammed by a lateral moraine, which created a small closed basin with a terminal lake. A sediment package of more than $4.5 \mathrm{~m}$ occurs between the lake and the moraine, whereas the top of the sediments correlates with a high paleolake level. 

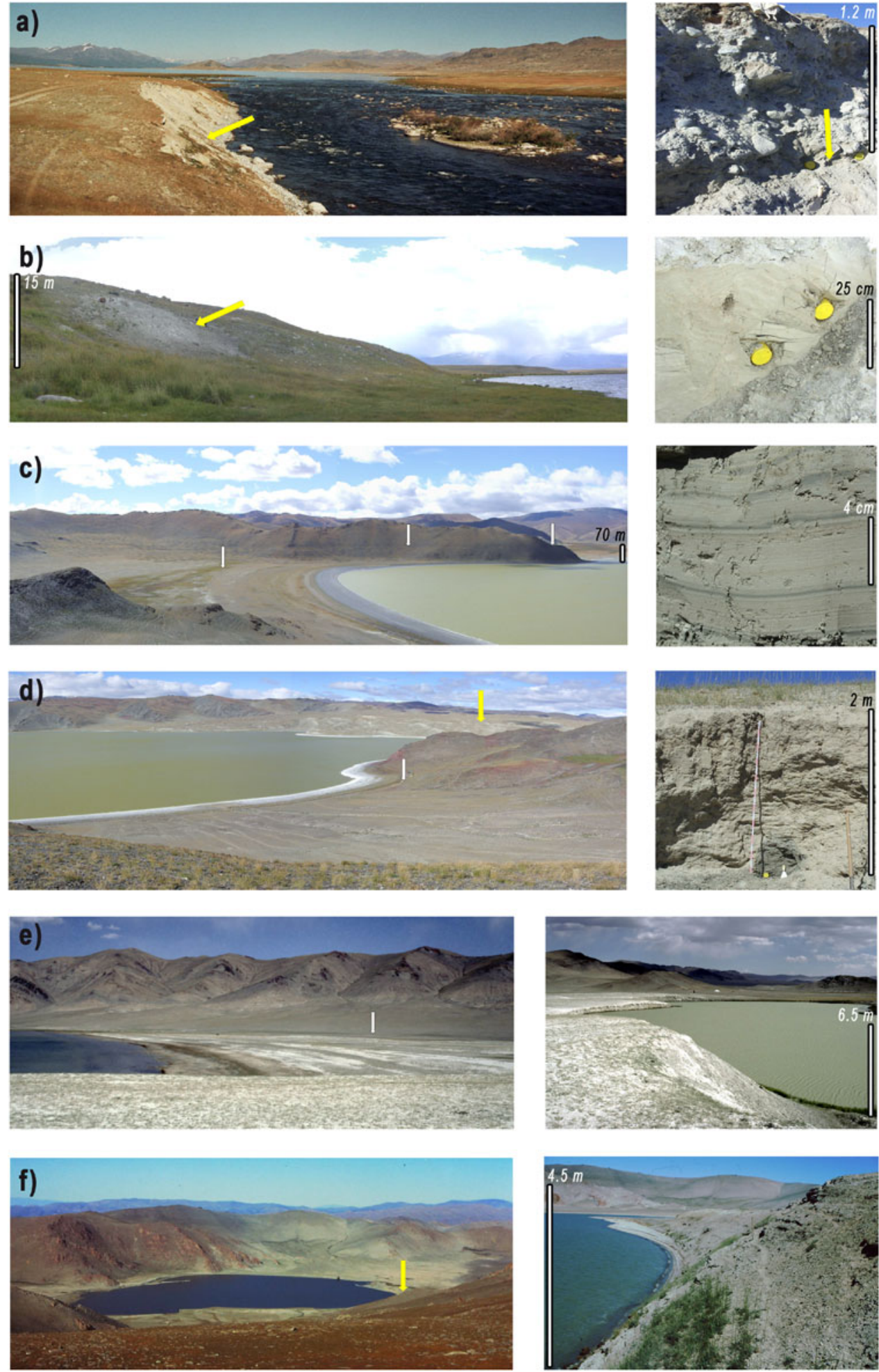

Figure 3. Photographs showing the landscape and the sedimentary sections at the different investigation sites. The yellow arrows indicate the position of the dated sediment profiles. The yellow tubes in the pictures on the right are the luminescence sampling tubes $(6 \mathrm{~cm}$ diameter). The white arrows indicate the position of the cliff and the highest shoreline. (a) Site A1: terminal moraine at Khoton Nuur. (A1) Layer of aeolian sediment within till $\left(48^{\circ} 35.8^{\prime} \mathrm{N}, 88^{\circ} 25.5^{\prime} \mathrm{E}\right)$. (b) Site A2: Terminal moraine at Khurgan Nuur. (A2, A3) Lacustrine sediments within till $\left(48^{\circ} 46.7^{\prime} \mathrm{N}, 88^{\circ} 46^{\prime} \mathrm{E}\right)$. (c) Site B: Cliff and shorelines at the lake in the closed basin at Tsagaan Gol (view to south). (B4) Stratified lacustrine sediments $\left(49^{\circ} 0.8^{\prime} \mathrm{N}, 88^{\circ} 33.8^{\prime} \mathrm{E}\right)$. (d) Site B: Terminal moraine damming the lake at Tsagaan Gol (view to west). (B5) Lacustrine sediments upon terminal moraine $\left(49^{\circ} 0.8^{\prime} \mathrm{N}, 88^{\circ} 33.8^{\prime} \mathrm{E}\right)$. (e) Site C: Lacustrine sediments with plant remains and strandlines at Ekhen Nuur basin $\left(49^{\circ} 25.5^{\prime} \mathrm{N}, 8^{\circ} 45^{\prime} \mathrm{E}\right)$. (f) Site D: Lake in closed basin dammed by a lateral moraine at Munkh Khairkhan with stratified sediments (view to north) $\left(46^{\circ} 56.5^{\prime} \mathrm{N}, 91^{\circ} 37^{\prime} \mathrm{E}\right)$. (For interpretation of the references to color in this figure legend, the reader is referred to the web version of this article.) 


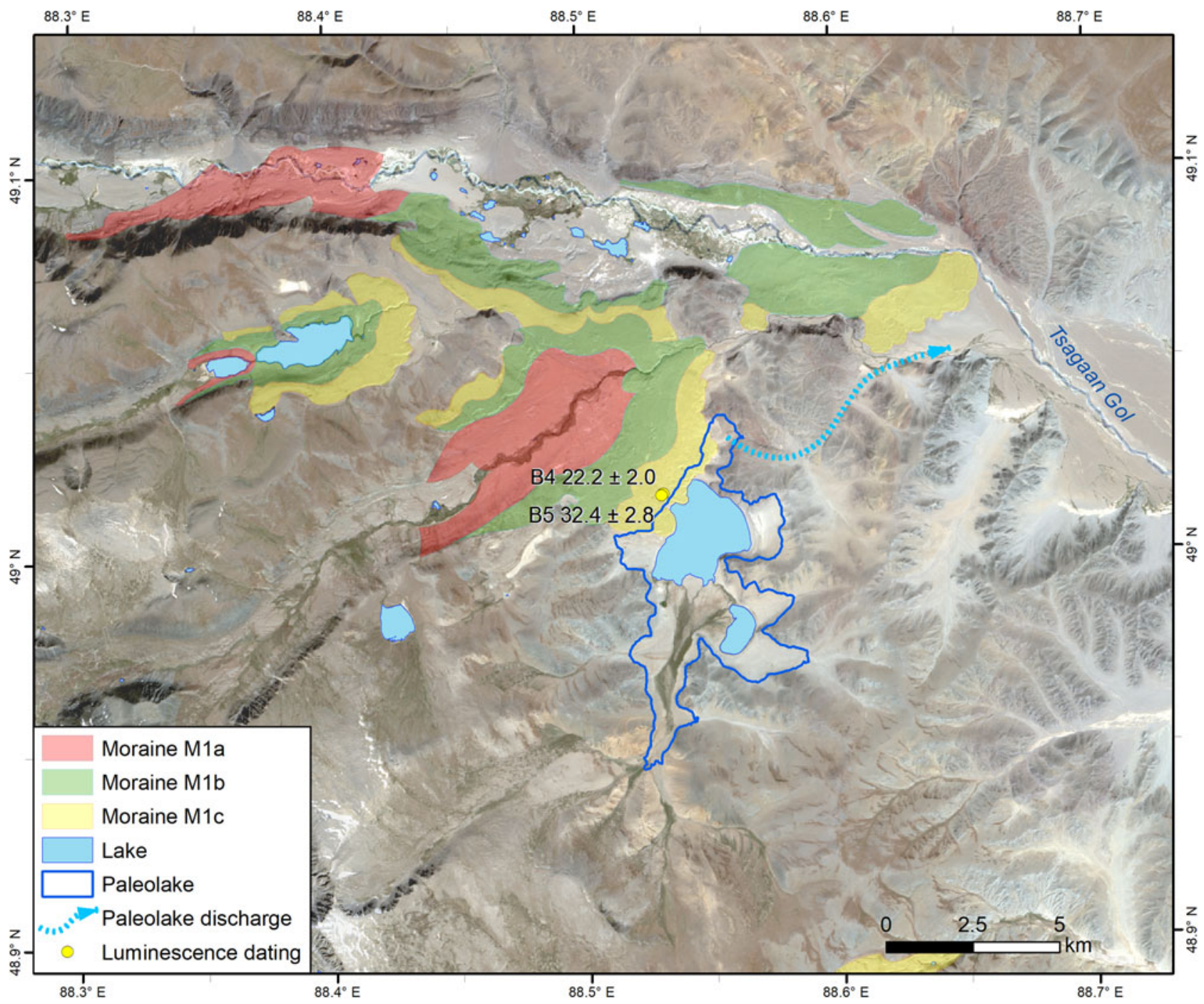

Figure 4. (color online) Glacial morphology and sampling site B in a southern side valley of the Tsagaan Gol. The background Landsat 8 satellite image was recorded on August 31, 2014.

The sediments consist of alternating layers of lacustrine clay, clayey limestone, silt, and layers rich in plant remains. Section D7 is a cliff eroded in these sediments by the lake (Fig. 3f). The plant-rich layers were sampled systematically for pollen analysis and ${ }^{14} \mathrm{C}$ dating (Table $1, \mathrm{D}$ ). The ${ }^{14} \mathrm{C}$ dates (43.4-27.7 cal ka BP) are all MIS 3 (see Table 2, D7), but exhibit low age-depth relation. As no carbonate bedrock exists in the area, the scattering ages may indicate a reservoir effect by carbonates from eolian silt material. For carbonate in lacustrine sediments at Gun Nuur in northern Mongolia, Feng et al. (2005) reported a carbon reservoir effect of $1200 \mathrm{yr}$.

\section{Palynological results from Ekhen Nuur and Munkh Khairkhan}

In total, we identified 70 pollen, 6 spore, and 3 algae taxa. A selection of taxa is presented in Figures 7 and 8. The diagram for the Ekhen Nuur (Fig. 7) is divided into two local pollen zones (LPZ) due to changes in taxon presence and sedimentology. In the Munkh Khairkhan diagram (Fig. 8), four humid pulses are interpreted.

Like dating from many other lake sediments in Mongolia and arid Asia, the ${ }^{14} \mathrm{C}$ ages exhibit the well-known phenomenon of not being free from inconsistencies, most probably relating to reservoir effects (Yan et al., 2011; Felauer et al., 2012; Wang et al., 2017; Yu et al., 2019). The ${ }^{14} \mathrm{C}$ reservoir ages of water plants taken over a few years from the same site can vary up to $1 \mathrm{ka}$ and are dependent on precipitation (Philippsen and Heinemeier, 2013). The age variation in the Munkh Khairkhan may refer to unstable water conditions expressed in strong fluctuation of water plant composition and wet pulses (see "Palynological Results from Ekhen Nuur and Munkh Khairkhan"). When the one extremely old age is discarded as an outlier, the Munkh Khairkhan pollen data represent some millennia around $30 \mathrm{ka}$. At Ekhen Nuur, the dating perfectly matches the Younger Dryas 


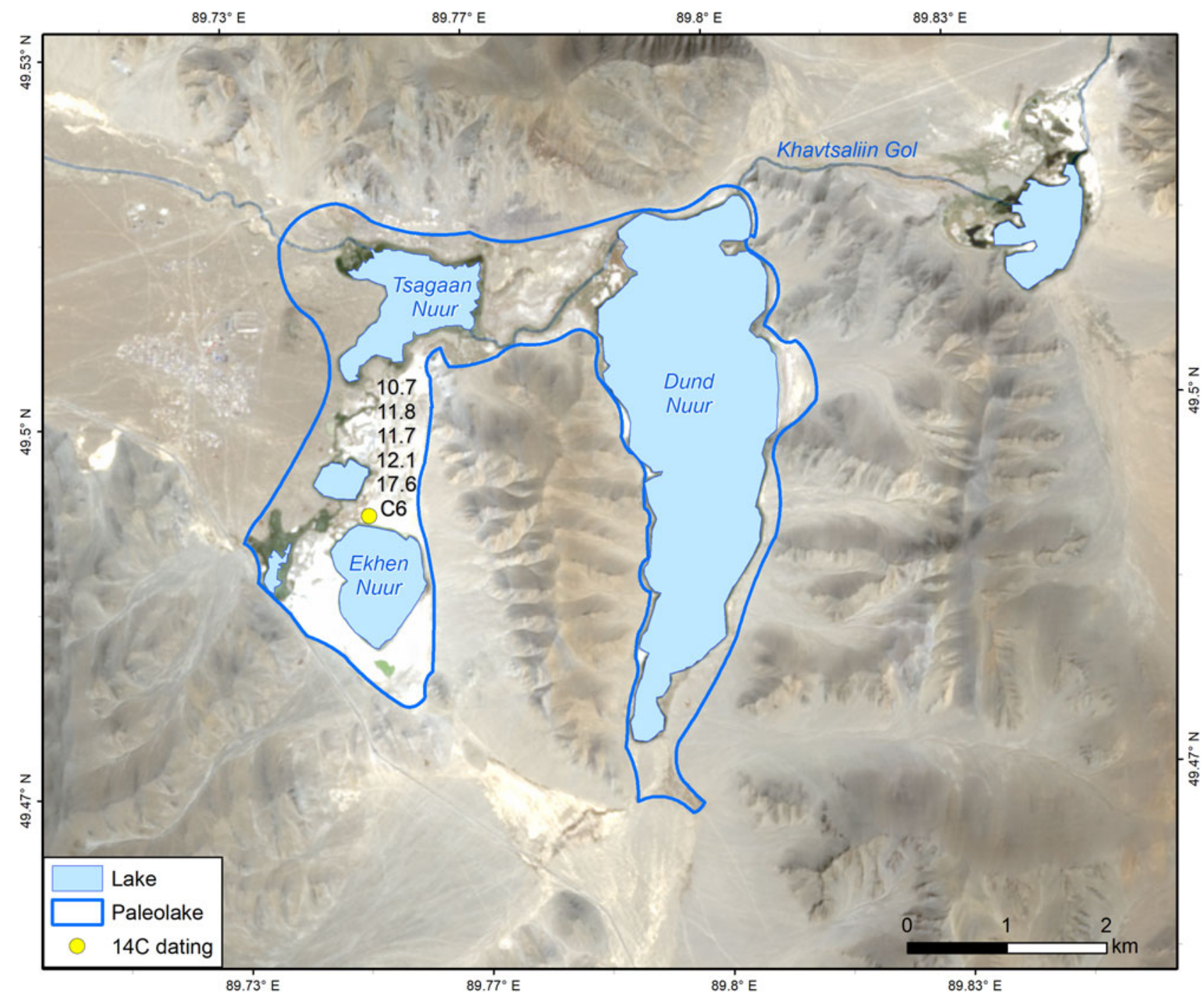

Figure 5. (color online) Map showing the lake level change of $+6.5 \mathrm{~m}$ from late glacial to Early Holocene at the Ekhen Nuur site C. Samples for palynology and ${ }^{14} \mathrm{C}$ dating (in cal ka BP) were sampled from a cliff near Ekhen Nuur. The background Landsat 8 satellite image was recorded on August 31, 2014.

(YD) age of the sand layer and reach to the top $1 \mathrm{ka}$ into the early Holocene.

\section{Ekhen Nuur (site C)}

The pollen spectra are dominated by $P$. sibirica (average $17 \%$, up to nearly $28 \%$ ), Artemisia $(29 \%, 37 \%)$, Chenopodiaceae $(26 \%, 29 \%)$, and Poaceae $(8.5 \%, 13 \%)$ (Fig. 7$)$. The two pollen spectra of LPZ 1 represent the late Pleistocene shortly before the start of the YD. The YD is represented by sandy sediments, which separate the lower part of the section from the upper one. Due to the overall climatic situation and the climate needs of conifer trees, the pollen grains of Pinus, Picea, and Abies in the lake sediments most probably do not reflect trees that were local or regional at that time; their origins are more likely from long-distance transport or a redeposition of older sediments of possibly early Pleistocene age, as exemplified by Tsuga (Grichuk, 1997). The increase of the tree species $L$. sibirica and $P$. obovata and the later increase of
P. sibirica and especially A. sibirica point to a gradual expansion of dark boreal taiga into the Mongolian Altai from the north during the Early Holocene (LPZ 2). The spores of Diphasiastrum support the interpretation of taiga expansion, as these clubmosses are widely spread in the Siberian taiga and are found in Mongolia today only in areas with Abies sibirica. As A. sibirica is the most moisture demanding, and therefore the most-restricted coniferous tree in Mongolia, the climate must have been considerably wetter during the Early Holocene. The occurrence of dark taiga with $A$. sibirica hints at about 200-300 $\mathrm{mm}$ more precipitation in the Mongolian Altai than today, which is a precipitation increase already claimed for the southern Mongolian Altai and the Gobi Altai during the Mid-Holocene (Jäger, 2005; Miehe et al., 2007). This means an approximate doubling of precipitation compared with today (Academy of Sciences of Mongolia and Academy of Sciences of USSR, 1990). The resulting higher water runoff may have favored Hippophae rhamnoides growing as a shrub or small tree on unconsolidated sand and 


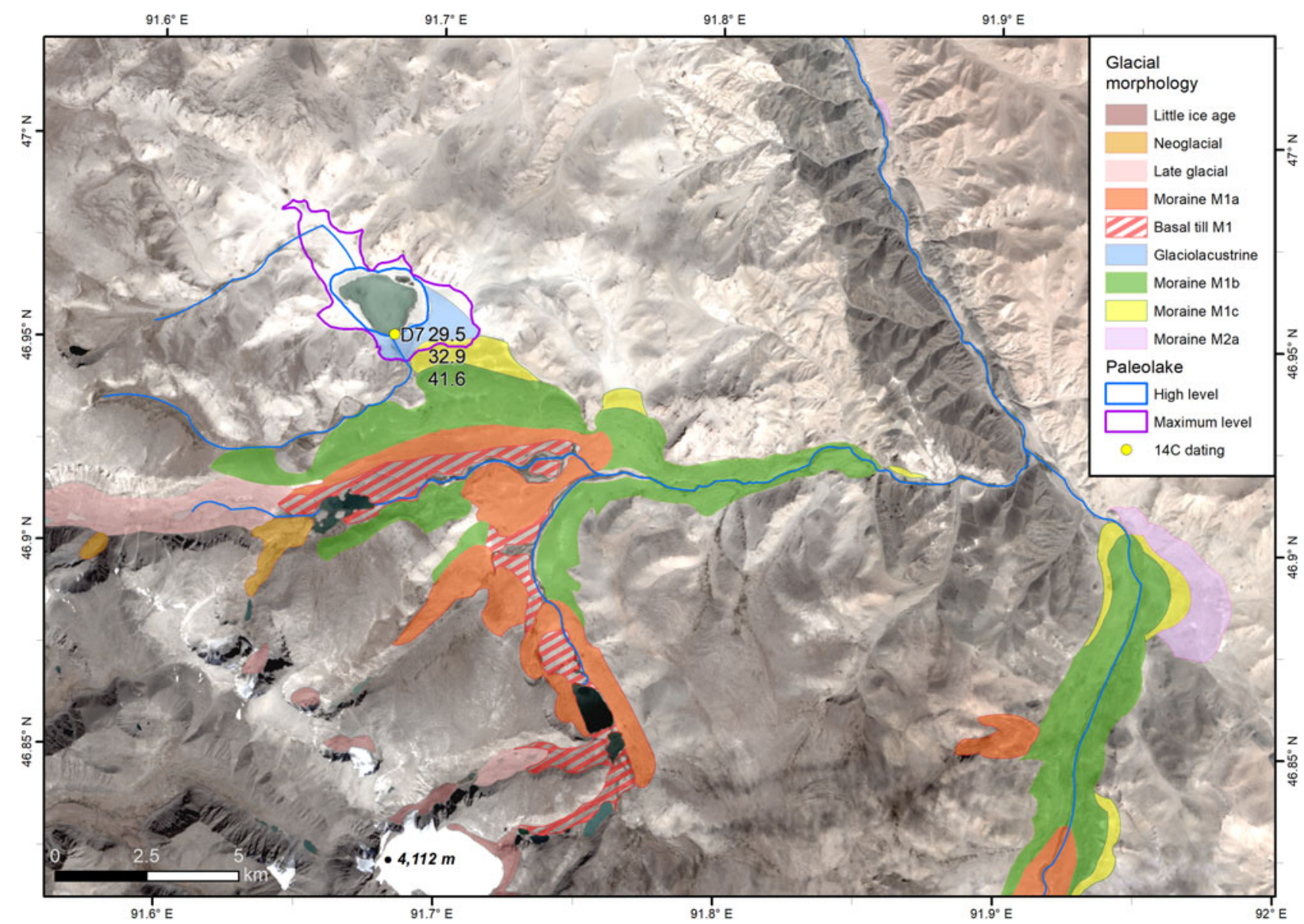

Figure 6. (color online) Glacial morphology and sampling site (D7) at the east of the Munkh Khairkhan. Samples for palynology and ${ }^{14} \mathrm{C}$ dating (in cal ka BP) were sampled from a cliff near a small moraine-dammed lake. The background Landsat 8 satellite image was recorded on September 2, 2014.

pebble along active watercourses. As steppes (Poaceae, Thalictrum) and desert steppes (Chenopodiaceae) existed throughout the late Pleistocene to Early Holocene without major shifts, the dark taiga may have formed some kind of forest-steppe, with forests restricted to more humid sites. Pollens like the Myriophyllum spicatum- $(3.8 \%, 5.3 \%)$ and Batrachium-type $(1.1 \%, 2.4 \%)$ indicate plant communities in a permanent water body of about $0.5 \mathrm{~m}$ depth (Hilbig, 1995), accompanied in the beginning by Potamogeton. The later appearance of Sparganium, Polygonum amphibium, and Hippuris may relate to temperature amelioration. Colonies of the green algae Pediastrum simplex were very common in the lake. This Pediastrum species tolerates salt- and carbonate-rich waters, pointing to alkaline conditions and possibly a more or less endorheic situation of the lake under strong evaporation (Lenarczyk et al., 2015).

\section{Munkh Khairkhan (site D)}

The wind-transported pollen from Artemisia (average 62\%, maximum 69\%), Chenopodiaceae $(19 \%, 25 \%)$, and Poaceae $(5.6 \%, 14 \%)$ dominate the spectra; P. sibirica $(0.3 \%, 0.9 \%)$, and other conifers appear infrequently with low values
(Fig. 8). In contrast, the plants of Nitraria, Atraphaxis, Calligonum, and the Limonium-type are insect pollinated. Of these taxa, only the Nitraria has pollen reported with some regularity from Mongolian paleo-archives (Felauer et al., 2012; Sun et al., 2013; Yu et al., 2019). Nitraria, Atraphaxis, and Calligonum are typical shrubs or semishrubs of the desert steppes and especially of the Mongolian full deserts (Hilbig, 1995). Representatives of Nitraria and the Limonium-type (Limonium, Goniolimon) grow on salty and alkaline soils (Grubov, 2011). The climatic conditions near the study site must have been much drier than today. The (semi-)arid vegetation belt that exists today in the nearby Achit Nuur basin was shifted upward by about $500 \mathrm{~m}$ to the Ekhen Nuur. Considering the influence of low temperatures close to the LGM on the water balance, the precipitation must have been reduced drastically, most possibly by more than $200-300 \mathrm{~mm}$ compared with today. As is typical for desert environments, precipitation may have varied much over time, with prevailing very dry conditions alternating with relatively wet pulses. Synchronously higher values of $H$. rhamnoides, growing along active watercourses, and of the water algae Botryococcus $(13,268$, and $402 \mathrm{~cm})$ may indicate the heavy rainfall events typical of such episodes. Another possible moisture pulse 


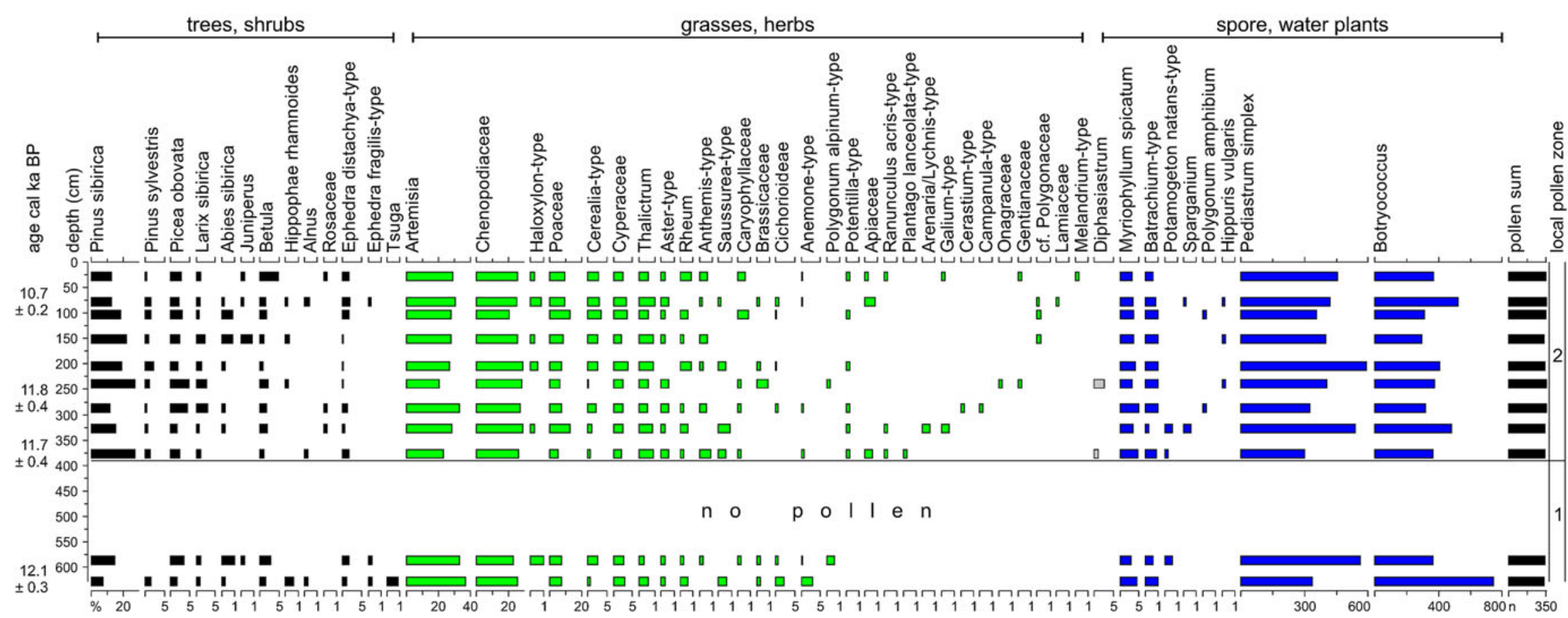

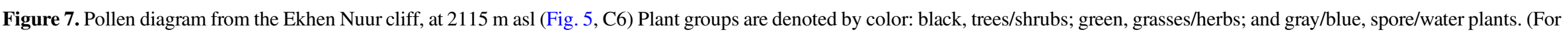
interpretation of the references to color in this figure legend, the reader is referred to the web version of this article.) 


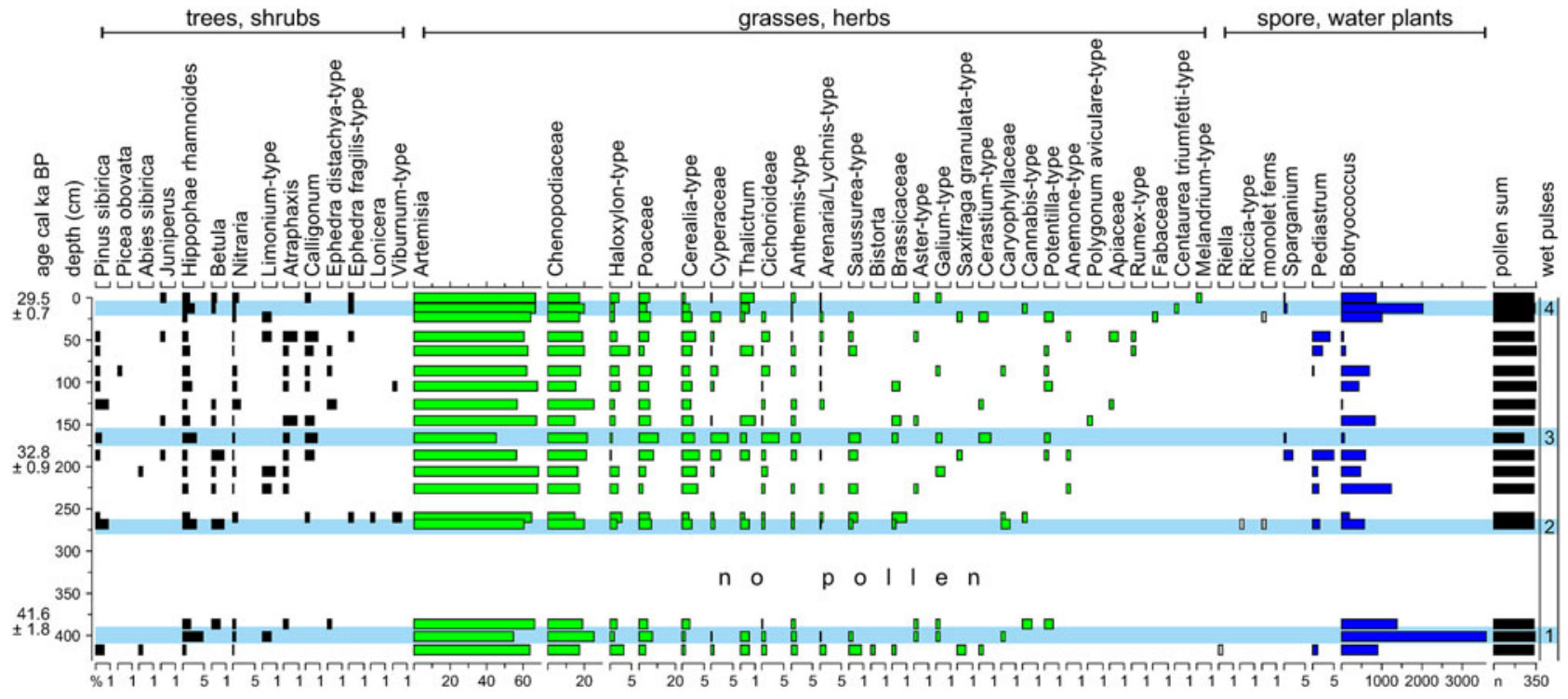

Figure 8. Pollen diagram from the Munkh Khairkhan study site, at $2730 \mathrm{~m}$ asl (Fig. 6, D7). Plant groups are denoted by color: black, trees/ shrubs; green, grasses/herbs; and gray/blue, spore/water plants. Selected dating represent the approximate time frame of the archive. (For interpretation of the references to color in this figure legend, the reader is referred to the web version of this article.)

$(166 \mathrm{~cm})$ can be inferred from the highest increase in Poaceae, Cyperaceae, and Cichorioideae (Asteraceae with fenestrate pollen grains). The absence of vascular water plants might point to unstable water conditions and/or low winter temperatures causing long ice covers on the lake.

\section{DISCUSSION}

The maximum glaciated area of the late Pleistocene in Mongolia, as delineated from satellite images and based on field experience, and the locations discussed in the following text are shown in Figure 9. The temporal distribution of glaciation and paleolakes reported in the literature is illustrated in Figure 10. In the following text, the numbers in the parentheses after the locations refer to the numbers in Figures 9 and 10.

\section{Regional timing of late Pleistocene glaciations in Mongolia}

As shown in this study and reported by Lehmkuhl et al. (2016), the terminal moraine complex of Khurgan Nuur consists of three main stages between 88 and $16 \mathrm{ka} .{ }^{10} \mathrm{Be}$ dating of glacial deposits in the Ikh Turgen massif in the northwestern part of the Mongolian Altai were performed by Blomdin et al. (2018). For two moraine complexes of maximum stages at the eastern side of the mountains (1), the authors reported ages of 45 and $\sim 23 \mathrm{ka}$. In contrast, a wide scatter of ages between 53 and $\sim 14 \mathrm{ka}$ from samples of two moraine complexes at the hummocky terrain on the western side of Ikh Turgen (2) did not provide distinct information for the timing of mean glacial stages. Poetsch (2017) performed ${ }^{10} \mathrm{Be}$ analyses on boulders of moraines and roche moutonée at the eastern side of the Turgen-Kharkhiraa Mountains, which are located in the northeastern part of the Mongolian Altai (3). The author reported a maximum glacial expansion around 81-78 ka corresponding to MIS 5a and a major ice advance between 26 and $20 \mathrm{ka}$. The last maximum terminal glacial position occurred between 19 and $16 \mathrm{ka}$ during the first part of the LGP before the glacier completely retreated. Here, no evidence for a MIS 3 glacial stage was found. Glacial deposits in the Sutai range (4), which is located in the southeastern part of the Mongolian Altai in the transition region to the Gobi Altai, were examined for ${ }^{10} \mathrm{Be}$ dating by Batbaatar et al. (2018). For moraines of maximum glacial extension, the authors reported ages of $\sim 27-22 \mathrm{ka}$ on the eastern side of range and $\sim 19-14 \mathrm{ka}$ on the western side. Additional ${ }^{10} \mathrm{Be}$ investigations exist for the neighboring regions of the Mongolian Altai. In the Chuja basin to the west (5), Gribenski et al. (2016) reported MIS 2 for the LGM, with deglaciation around 19 ka. In addition, Reuther et al. (2006) reported cataclysmic outburst floods from a big lake, which existed in the Chuja basin due to glacial damming, around 18 ka (Gribenski et al., 2018). Gribenski et al. (2018) examined glacial deposits around the Kanas Lake (6), which is situated in the southwestern part of the Altai within Chinese territory. The authors reported MIS 2 for the ILGM and another glacial advance around late MIS 5/MIS 4, but they could not confirm the assumed MIS 3 advance by Zhao et al. (2013) and Xu et al. (2009). Moreover, Gribenski et al. (2018) disputed in general the evidence of a pronounced MIS 3 glacial advance for all of central Asia.

In the Darhad basin (7), which is located in northern Mongolia, Gillespie et al. (2008) and Batbaatar and Gillespie (2016b) reported glacial advances between $\sim 53-35$ and 27-19 ka. The advancing glaciers from the East Sayan Mountains had dammed the Maly Yenisei River and a deep lake 


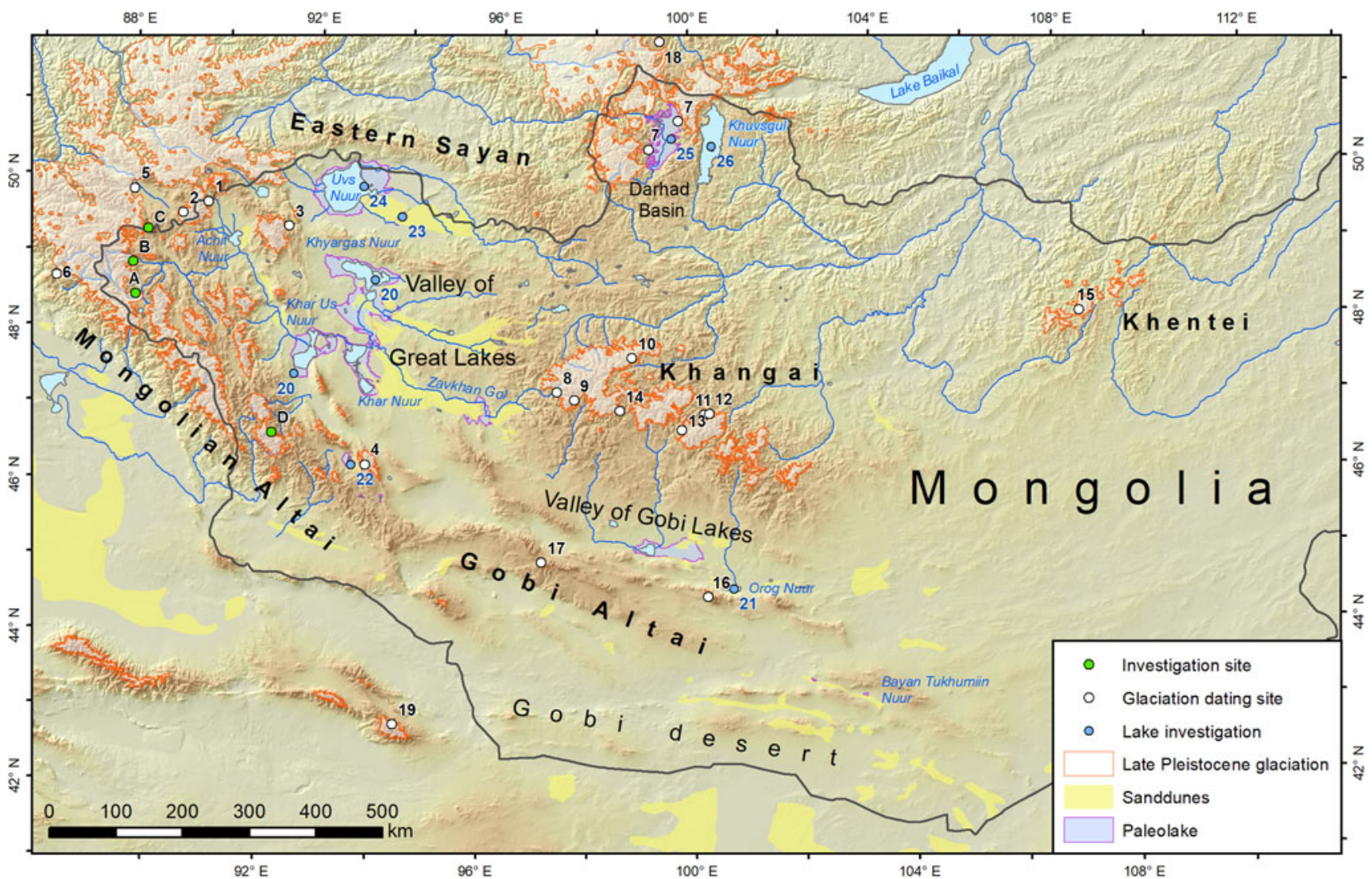

Figure 9. (color online) Late Pleistocene glaciation and paleolake levels in Mongolia. The Pleistocene glaciated area in the region of Mongolia was mapped on the basis of satellite images (Landsat and Sentinel), whereas the glaciation of the western Altai and southern Siberia was taken from Ehlers et al. (2011). The site numbers and letters refer to locations mentioned in the text and in Fig. 10. (1,2) Ikh Turgen, (3) Turgen-Kharkhiraa, (4) Sutai Uul, (5) Chuja basin, (6) Kanas Lake, (7) Darhad basin, (8,9) Otgon Tenger, (10) Gyalgar peak, (11) Chuluut Gol, (12) Bumbat valley, (13) Egiin Davaa, (14) Khukh Nuur, (15) Khentei, (16) Ikh Bogd, (17) Gichiginii range, (18) East Sayan Mountains, (19) Karlik range, (20) Khar Us Nuur/Khyargas Nuur (great paleolake), (21) Orog Nuur, (22) Tsetseg Nuur, (23) Bayan Nuur, (24) Uvs Nuur, (25) Darhad paleolake, (26) Khusgul Nuur, (A) Khurgan Nuur/Khoton Nuur, (B) Tsagaan Nuur, (C) Ekhen Nuur, (D) Munkh Khairkhan.

existed in the Darhad basin between 21 and $17 \mathrm{ka}$. Subsequently, the deep lake persisted episodically until $\sim 14 \mathrm{ka}$, probably dammed by the outwash plain of the readvancing Tengis glacier, until Darhad basin fell largely dry after $\sim 10$ ka. At the eastern Sayan Mountains in southern Siberia (18), Arzhannikov et al. (2012) and Batbaatar and Gillespie (2016b) performed ${ }^{10} \mathrm{Be}$ dating on moraines in four different main valleys running to the east. The authors reported glaciations at $\sim 22, \sim 16$, and between 12 and $10 \mathrm{ka}$. Several investigations on glacial sediments with ${ }^{10} \mathrm{Be}$ dating exist for the Khangai Mountains in central Mongolia, which provide ages between MIS 3, MIS 2, and the LGP. From the western side of Otgon Tenger peak (8), Rother et al. (2014) reported maximum glacial extents between 44 and 33, 23, and 17-16 $\mathrm{ka}$, whereas Batbaatar et al. (2018) reported ages of $\sim 33-28$ and $\sim 17-16 \mathrm{ka}$ for moraines at the eastern side of Otgon Tenger (9). ${ }^{10} \mathrm{Be}$ dating from moraines in the eastern part of the Khangai Mountains are reported for the Gyalgar peak (10) by Batbaatar and Gillespie (2016b), with ages between 30 and $17 \mathrm{ka}$ (average $24 \mathrm{ka}$ ) and by Smith et al. (2016) with ages of $\sim 15 \mathrm{ka}$; for the Chuluut Gol (11), by Smith et al. (2016) with ages of $22 \mathrm{ka}$ and by Poetsch (2017) with mean ages between 41 and $16 \mathrm{ka}$; for the nearby Bumbat valley (12), by Batbaatar et al. (2018) with ages of 39-31 $\mathrm{ka}$; for the Egiin Davaa area (13), mean ages of 49 and 2625 ka by Poetsch (2017); and for the Khukh Nuur (14), by Smith et al. (2016) ages between 44 and $14 \mathrm{ka}$. In the Khentei Mountains (15), which are located in the northeastern part of Mongolia, Khandsuren et al. (2019) reported ${ }^{10} \mathrm{Be}$ ages from boulders upon moraines of $\sim 21-19$ and 18-16/12 ka. Batbaatar et al. (2018), who performed ${ }^{10} \mathrm{Be}$ dating from moraines in the Gobi Altai, reported late glacial ages ( 17-13 ka) for the Ikh Bogd (16) and Holocene ages at the Gichginii range (17). At the Karlik range in the southern Gobi (19), Chen et al. (2015) reported four major glaciation events. Three moraine stages were dated by ${ }^{10} \mathrm{Be}$ analysis to $\sim 0.8,14-18$, and 60 $79 \mathrm{ka}$, whereas one stage was dated by OSL between 37.4 and $44.2 \mathrm{ka}$.

Summarizing the investigations and the data about maximum glacial advances in the region of Mongolia shows diverging periods for the oldest stage of the last glacial period that can range between MIS 5a (Turgen-Kharkhiraa, Khurgan Nuur, Kanas Lake, Chuluut Gol), and MIS 3 (Ikh Turgen, Khangai Mountains, Karlik range). A MIS 4 age is reported 


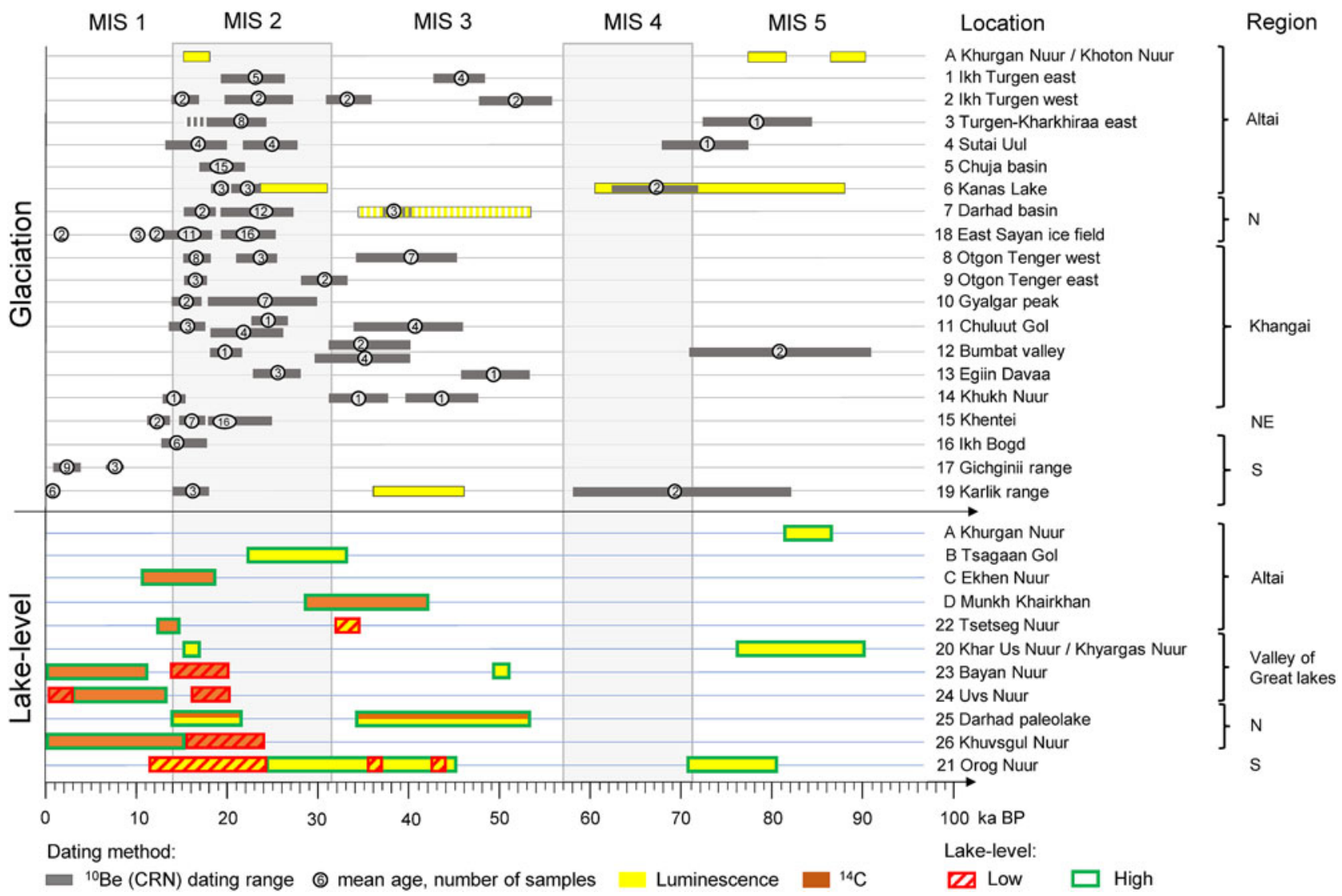

Figure 10. (color online) The temporal distribution pattern of dating for glacial extents and paleolake levels for different regions of Mongolia. The horizontal bars cover the total period framed by the time range of the dated samples, excluding specified outliers. The gaps between the indicated states are due to missing data. The numbers of the different sites correspond with Fig. 9 and refer to the text. The capital letters refer to the study sites referenced in Fig. 1 and in the text. Vertically striped bars indicate indirect age determination.

for the Kanas Lake moraine. The two main moraines of LGM and the LGP are generally present in every mountain range. In the next step, we will discuss the findings about paleolakelevel distribution and paleo-vegetation with respect to the delineation of climate conditions during the different glacial stages of the late Pleistocene.

\section{Evaluation of late Pleistocene periods of environmental change}

\section{Glacial advances before the LGM (MIS 5a-b)}

The proglacial lacustrine sediments at Khurgan Nuur (Figure 2, A2), which probably had been eroded and incorporated into an advancing glacier, indicate a glacial stage before and after 88-85 ka. In combination with the moraine ages reported by Poetsch $(2017 ; 81-78$ ka) from the Turgen-Kharkhiraa Mountains and by Gribenski et al. (2018; 79-63 ka) at Kanas Lake, these glacial advances can be classified into the period MIS 5a-b. Devyatkin (1981) assumed a high paleolake level at Khyargas Nuur (20) between 90 and $76 \mathrm{ka}$. A high lake level at Orog Nuur (21) in the Gobi Desert to the southeast between 80 and $70 \mathrm{ka}$ was reported by Lehmkuhl and Lang (2001) and Lehmkuhl et al. (2018). No climatic evidence from pollen records and further high lake levels exist for this period in the region of western Mongolia. Inferred from the documented glacial advances, which represent a maximum extension of the last glacial period $\left(\mathrm{M}_{1 \mathrm{c}}\right)$ and the occurrence of paleolakes, this period can be correlated to cold and humid conditions at the current stage of knowledge.

\section{Anaglacial glacial advances (MIS 3/2)}

The high levels of the proglacial paleolakes at the Tsagaan Gol (B4, B5) between 32 and 22 ka and at Munkh Khairkhan (D7) between 42 and $29 \mathrm{ka}$ occurred in the transition period between MIS 3 and 2. During the phase of glacier buildup and advance, the lacustrine sediments were deposited upon the till of the $\mathrm{M}_{1 \mathrm{c}}$ moraines. The large amount of sediment input from slopewash and eolian silt and the precipitation of carbonate indicate dry conditions in this mountain region for that period. The desert-like vegetation inferred from palynology (Fig. 8) underlines a dry climate. The overall dry conditions were interrupted by short phases of enhanced effective moisture. Regarding the arboreal desert elements (Nitraria, Atraphaxis, Calligonum), including H. rhamnoides, the mean temperature of the coldest month at the 
Munkh Khairkhan might have been at minimum around $-20^{\circ}$ $\mathrm{C}$, that of the warmest month about $6^{\circ} \mathrm{C}$ to $10^{\circ} \mathrm{C}$, and the minimum annual precipitation during the growing season could have been as low as about 20-30 mm. Overall, the taxa mentioned allow a potential evapotranspiration in a range of up to 300-900 mm (Fang et al., 2011).

For the Tsetseg Nuur Basin (22) in the southern Mongolian Altai, Klinge and Lehmkuhl (2013) reported a low lake level around $33 \mathrm{ka}$, which was indicated by the accumulation of eolian sand in the basin and interpreted as a dry period. For the period between 45 and $24 \mathrm{ka}$, Yu et al. (2019) reported higher lake levels at Orog Nuur (21) in the Gobi Desert, which they related to increased precipitation, interrupted by lake desiccations at $\sim 43$ and $\sim 36 \mathrm{ka}$. For the Bayan Nuur (23) in the east of the Uvs Nuur, Naumann (1999) and Grunert et al. (2000) reported a high lake level around $50 \mathrm{ka}$. Gillespie et al. (2008) and Batbaatar and Gillespie (2016a) reported that a deep lake existed intermittently in the Darhad basin during MIS 3 (53-35 ka) in northern Mongolia, based on ${ }^{14} \mathrm{C}$ and luminescence dating of lake sediments at a high shoreline. Based on pollen analysis from the Shaamar eolian-paleosol section in northern Mongolia, Ma et al. (2013) assumed a wet period between 38 and $\sim 30 \mathrm{ka}$ and cold and dry conditions for the following period of $\sim 30-23 \mathrm{ka}$.

A general change from humid to drier conditions occurred during this cold period, but with spatial disparity. The different evolution of lake levels is obviously evident for different environmental settings in the catchment areas. Tsetseg Nuur has a large catchment reaching into the high mountain environments, where developing glaciers and permafrost accumulated a large portion of water and reduced the discharge into the basins. Bayan Nuur is situated in relatively low elevation in the basin (932 $\mathrm{m}$ asl), and the proglacial lakes in the mountains have only small catchments where no extensive glaciation existed. Although precipitation decreased, with mostly dry conditions indicated by the vegetation in the surrounding area, higher lake levels could have developed due to low evaporation and cool temperatures. With the exception of the terminal lakes in the Valley of Gobi lakes, which are fed by rivers from the Khangai Mountains, the paleolakes in the southernmost Gobi region did not have extensive high mountainous areas or glaciation in the catchment area. Thus, the higher lake levels could have been due to low evaporation as well as to a diverging precipitation regime.

\section{LGM 26-18 ka (middle of MIS 2)}

The most obvious glacial advance $\mathrm{M}_{1 \mathrm{~b}}$ in Mongolia, which is indicated by well-preserved moraines, occurred between 26 and $18 \mathrm{ka}$ and was generally accompanied by low lake levels. Grunert et al. (2000) reported very low lake levels and even desiccation at Uvs Nuur (24) between 20 and $16 \mathrm{ka}$, and Bayan Nuur (23) did not exist until 14 ka (Naumann, 1999). During the LGM, the Khuvsgul Nuur (26) in northern Mongolia was at its lowest stand, about $100 \mathrm{~m}$ below the recent level, and had no outflow (Prokopenko et al., 2005), which points to dry conditions and water retention in glacier ice and ground ice. The contempory existence of a large and deep lake in the Darhad basin (25) since 21 until $14 \mathrm{ka}$ (Gillespie et al., 2008), which was impounded by a glacier dam, resulted independent of climate. In contradiction, Sun et al. (2013) inferred wet conditions for the period 22.6$13.2 \mathrm{ka}$ based on pollen spectra from Achit Nuur sediments interpreted as forest-steppe. However, the extreme low pollen concentration reported for that period compared to the Holocene pollen concentration seems to contradict a welldeveloped vegetation cover under a quite humid climate.

Proxy data from southern Mongolia also point to a dry climate in that region. Based on the OSL dating of eolian sands from Zavkhan Gol, which drains the Khangai Mountains to the west, and from Bayan Tukhumiin Nuur, a desiccated lake in the Gobi, a dry phase was reported by Lehmkuhl et al. (2018) for the MIS 2. After $24 \mathrm{ka}$, the Orog Nuur desiccated and remained a shallow saline lake until $11 \mathrm{ka}(\mathrm{Yu}$ et al., 2019).

The ILGM represents the culmination of cooling and drying of the last glaciation. The increasing gradient of the glacial snowline from west to east provides evidence for the depletion of effective moisture supply mainly controlling the strong aridity in that region (Lehmkuhl et al., 2011). However, the few existing investigations on vegetation distribution for that period point to a change from arid to more humid conditions already occurring around $23 \mathrm{ka}$. The temporal shift between the proxy data for precipitation derived from vegetation, lake levels, and glaciation could be explained by a more rapid adaptation to climate change of the vegetation in the basins than the glaciers in the mountains. Vegetation is more sensitive to changes in precipitation and temperature than glaciers and lake levels. Interference from different archives can originate from different response times of the corresponding proxies. As inferred from the pollen archive of the Munkh Khairkhan, the precipitation would have varied much over time, including during wet pulses and prevailing desert conditions before the LGM. Minimally higher but more reliable precipitation during the vegetation periods around the turn to the LGM could have caused noticeable changes in vegetation, possibly without distinct budget changes of lakes or glaciers at the outset.

\section{LGP $(18-11 \mathrm{ka})$}

The eolian layer ( site A1) dated to 18-16 ka, which we found in between the till of the Khoton Nuur, classifies the terminal moraine $\mathrm{M}_{1 \mathrm{a}}$ as occurring in the early part of the LGP. The glacial advance reflects a cold stage, and the deposition of eolian sand and silts upon the glacier terminus indicates a sparse vegetation cover. The general glacial retreat after $16 \mathrm{ka}$, which was probably caused by a general trend of climate warming after the LGM (Klinge and Sauer, 2019), led to lake development in the tongue basin at the end of the LGP. Glacial processes and deposits controlled the development of the Khoton Nuur, whereas the concurrent high paleolake level at Ekhen Nuur in the Tsagaan Nuur basin (C6) reflects a water surplus. The intense input of eolian sediments is evidence for sparse 
vegetation cover in the surrounding landscape and extensive deflation from exposed paraglacial and postglacial sediments. Thus, the higher lake level occurred in the beginning under persistent cool conditions with decreased evaporation. With the onset of the Holocene, higher temperatures increased the evaporation. However, under an accompanying higher precipitation indicated by taiga forest expansion and possibly increased amount of melting water, it took about $1000 \mathrm{yr}$ for the lake to dry up at the investigated site.

The melting of glacier ice and permafrost ice was responsible for the high lake level of the Uvs Nuur between 13 and $11 \mathrm{ka}$ (Grunert et al., 2000). Using a pollen record from the Bayan Nuur, Tian et al. (2014) reconstructed high precipitation around $15.6 \mathrm{ka}$, whereas the lowest precipitation occurred between 12.4 and $11.9 \mathrm{ka}$. Based on eolian processes and sediments, Naumann (1999) reconstructed cold and dry conditions and desiccation of Bayan Nuur until around $14.2 \mathrm{ka}$. Then, a shallow, endorheic, and periodic lake developed, and the water level steadily rose until 11 $\mathrm{ka}$, when it reached up to $48 \mathrm{~m}$ above the present-day level and started to cut an outflow channel into the damming dune field. At Achit Nuur, Sun et al. (2013) reported desert and steppe vegetation indicating mild and dry conditions from 13.2 to $6.4 \mathrm{ka}$. Ma et al. (2013) stated that the climate became warmer and somewhat drier in northern Mongolia during the LGP until $11 \mathrm{ka}$ based on their investigations at the Shaamar section. At Khuvsgul Lake, the lake level start to rise beginning around $15.4 \mathrm{ka}$, and outflow occurred at the beginning of the Holocene, which was interpreted by Prokopenko et al. (2005) to be due to increased precipitation during the LGP. At Tsetseg Nuur, a high lake level was inferred for the LGP from a ${ }^{14} \mathrm{C}$ date of $13 \mathrm{cal} \mathrm{ka} \mathrm{BP}$ of mollusks and was attributed to the meltwater supply under the increasing temperature after the LGM (Klinge and Lehmkuhl, 2013). A high lake level after $17 \mathrm{ka}$ was also reported from the Khar Us Nuur, one of the three lakes in the southern Valley of Great Lakes (Lehmkuhl et al., 2016).

Paleoclimatic interpretations for the LGP diverge more concordant with the increasing number of investigated sites. The spatial and temporal variability of environmental conditions and sensitivity to climatic changes between different localities is due to regional settings such as relief, topography, catchment area, soil, geology, altitude, and latitude. Nevertheless, a trend of rising temperature is a common phenomenon for the LGP. On one hand, increasing temperatures caused the melting of glaciers and permafrost, which supplements the discharge into the basins. On the other hand, evapotranspiration also increases, leading to more arid conditions. The steep gradient of the modern snowline from $2600 \mathrm{~m}$ asl in the western Altai to more than $3700 \mathrm{~m}$ asl in the southeast indicates decreasing precipitation was the main parameter for limiting the glacier distribution and causing the aridity of the region (Lehmkuhl et al., 2011). Thus, it is more likely that the last glacial advance, $\mathrm{M}_{1 \mathrm{a}}$ during the early LGP, was driven by increasing precipitation. However, the possibility of local precipitation formation resulting from the large expansion of interior lakes is one of the questions that should be addressed by further research. It might be one of the missing pieces of the puzzle needed to better understand the apparent conflict among paleo-archives during this period.

\section{CONCLUSIONS}

The current state of knowledge about the paleoclimatic evolution of the Mongolian Altai during the late Pleistocene is scarce. The oldest remnants of late Pleistocene glacial deposits show that temperature decreased since at least $88 \mathrm{ka}$ (MIS $5 b)$, and a significant warming did not occur until the second half of the LGP $(\sim 13 \mathrm{ka})$. High precipitation induced the formation and advance of glaciers in the early part of the last glacial period $(\sim 50-30 \mathrm{ka})$ and also the persistence of glaciers during the early part of the LGP (18-14 ka). The main glacial advances of the LGM (26-21 ka) were triggered by the coldest temperatures under dry conditions. The interpretation of lake levels in terms of climate conditions needs to be crosschecked against environmental factors like hydrological connections to the high mountains, vegetation density, and geomorphological processes and events. More effective moisture can be caused by higher precipitation, but especially under dry continental conditions, the humidity determining evapotranspiration is also strongly related to the temperature regime. Thus, temperature plays an important part in lake levels and vegetation cover.

At present, it remains a challenge to deduce detailed paleoclimatic reconstructions for the Mongolian Altai during the late Pleistocene from the few and seemingly contradicting archives. Further research is needed to understand preanthropogenically forced (natural) climate change in this part of continental Eurasia.

\section{ACKNOWLEDGMENTS}

The authors would like to thank the Deutsche Forschungsgemeinschaft (HI 1398/3-1, LE 730/31-1, Schl 527/1-2) for their financial support. Fieldwork was supported by the Institute of Geography of the Mongolian Academy of Sciences. We thank A. Hilgers, D. Falk, H. Rother, S. Pötsch, and M. Walther for their support during the fieldwork and scientific discussions.

\section{REFERENCES}

Academy of Sciences of Mongolia and Academy of Sciences of USSR, 1990. National Atlas of the Peoples Republic of Mongolia. Ulan Baatar and Moscow.

Agatova, A.R., Nepop, R.K., 2019. Pleistocene fluvial catastrophes in now arid NW areas of Mongolian inland drainage basin. Global and Planetary Change 175, 211-225.

Arkhipov, S.A., Isayeva, L.L., Bespaly, V.G., Glushkova, O., 1986. Glaciation of Siberia and north-east USSR. Quaternary Science Reviews 5, 463-474.

Arzhannikov, S.G., Braucher, R., Jolivet, M., Arzhannikova, A.V., Vassallo, R., Chauvet, A., Bourlès, D., Chauvet, F., 2012. History of late Pleistocene glaciations in the central SayanTuva Upland (southern Siberia). Quaternary Science Reviews 49, 16-32. 
Barthel, H., 1983. Die regionale und jahreszeitliche Differenzierung des Klimas in der Mongolischen Volksrepublik. Studia Geographica 34, 1-91.

Batbaatar, J., Gillespie, A.R., 2016a. Outburst floods of the Maly Yenisei. Part I. International Geology Review 58, 1723-1752.

Batbaatar, J., Gillespie, A.R., 2016b. Outburst floods of the Maly Yenisei. Part II-new age constraints from Darhad basin. International Geology Review 58, 1753-1779.

Batbaatar, J., Gillespie, A.R., Fink, D., Matmon, A., Fujioka, T., 2018. Asynchronous glaciations in arid continental climate. Quaternary Science Reviews 182, 1-19.

Batima, P., Natsagdorj, L., Gombluudev, P., Erdenetsetseg, B., 2005. Observed climate change in Mongolia. AIACC Working Paper 12, 1-25.

Beug, H.-J., 2015. Leitfaden der Pollenbestimmung für Mitteleuropa und angrenzende Gebiete. 2nd ed. Verlag Dr. Friedrich Pfeil, Munich.

Blomdin, R., Heyman, J., Stroeven, A.P., Hättestrand, C., Harbor, J.M., Gribenski, N., Jansson, K.N., et al., 2014. Glacial geomorphology of the Altai and Western Sayan Mountains, central Asia. Journal of Maps 12, 123-136.

Blomdin, R., Stroeven, A.P., Harbor, J.M., Gribenski, N., Caffee, M.W., Heyman, J., Rogozhina, I., et al., 2018. Timing and dynamics of glaciation in the Ikh Turgen Mountains, Altai region, high Asia. Quaternary Geochronology 47, 54-71.

Bocharnikov, M.V., Ogureeva, G.N., Miklyaeva, I.M., 2015. Endemic formation of stitchwort polster (Stellaria pulvinata Grub.) in highlands of the Mongolian Altai. Arid Ecosystems 5, 142-153.

Böhner, J., 2006. General climatic controls and topoclimatic variations in central and high Asia. Boreas 35, 279-295.

Bøtter-Jensen, L., Andersen, C.E., Duller, G.A.T., Murray, A.S., 2003. Developments in radiation, stimulation and observation facilities in luminescence measurements. Radiation Measurements 37, 535-541.

Buylaert, J.P., Murray, A.S., Thomsen, K.J., Jain, M., 2009. Testing the potential of an elevated temperature IRSL signal from K-feldspar. Radiation Measurements 44, 560-565.

Chen, Y., Li, Y., Wang, Y., Zhang, M., Cui, Z., Yi, C., Liu, G., 2015. Late Quaternary glacial history of the Karlik Range, easternmost Tian Shan, derived from ${ }^{10} \mathrm{Be}$ surface exposure and optically stimulated luminescence datings. Quaternary Science Reviews 115, 17-27.

Clark, P.U., Dyke, A.S., Shakun, J.D., Carlson, A.E., Clark, J., Wohlfarth, B., Mitrovica, J.X., Hostetler, S.W., McCabe, A.M., 2009. The last glacial maximum. Science 325, 710-714.

Colarossi, D., Duller, G.A.T., Roberts, H.M., Tooth, S., Lyons, R., 2015. Comparison of paired quartz OSL and feldspar post-IR IRSL dose distributions in poorly bleached fluvial sediments from South Africa. Quaternary Geochronology 30, 233-238.

Devyatkin, E.V., 1981. Cenozoic of Inner Asia. [In Russian.] Nauka, Moskow.

Dinesman, L.G., Kiseleva, N.K., Knyazev, A.V., 1989. The History of Steppe Ecosystems of the Mongolian People's Republic. [In Russian.] Nauka, Moskow.

Dulamsuren, C., Welk, E., Jäger, E.J., Hauck, M., Mühlenberg, M., 2005. Range-habitat relationships of vascular plant species at the taiga forest-steppe borderline in the western Khentey Mountains, northern Mongolia. Flora-Morphology, Distribution, Functional Ecology of Plants 200, 376-397.

Duller, G.A.T., 2003. Distinguishing quartz and feldspar in single grain luminescence measurements. Radiation Measurements 37, $161-165$.
Durcan, J.A., King, G.E., Duller, G.A.T., 2015. DRAC: Dose Rate and Age Calculator for trapped charge dating. Quaternary Geochronology 28, 54-61.

Ehlers, J., Gibbard, P.L., Hughes, P.D. (Eds.), 2011. Quaternary Glaciations-Extent and Chronology: A Closer Look. Elsevier, Amsterdam.

Fang, J., Wang, Z., Tang, Z., 2011. Atlas of Woody Plants in China. Springer, Berlin.

Felauer, T., Schlütz, F., Murad, W., Mischke, S., Lehmkuhl, F., 2012. Late Quaternary climate and landscape evolution in arid Central Asia: a multiproxy study of lake archive Bayan Tohomin Nuur, Gobi Desert, southern Mongolia. Journal of Asian Earth Sciences 48, 125-135.

Feng, Z.-D., 2001. Gobi dynamics in the northern Mongolian Plateau during the past 20,000+ yr: preliminary results. Quaternary International 76/77, 77-83.

Feng, Z.-D., Wang, W.G., Guo, L.L., Khosbayar, P., Narantsetseg, T., Jull, A.J.T., An, C.B., Li, X.Q., Zhang, H.C., Ma, Y.Z., 2005. Lacustrine and eolian records of Holocene climate changes in the Mongolian Plateau: preliminary results. Quaternary International 136, 25-32.

Feng, Z.-D., Zhai, X.W., Ma, Y.Z., Huang, C.Q., Wang, W.G., Zhang, H.C., Khosbayar, P., Narantsetseg, T., Liu, K.-B., Rutter, N.W., 2007. Eolian environmental changes in the northern Mongolian Plateau during the past $\sim 35,000$ yr. Palaeogeography, Palaeoclimatology, Palaeoecology 245, 505-517.

Fowell, S.J., Hansen, B.C.S., Peck, J.A., Khosbayar, P., Ganbold, E., 2003. Mid to late Holocene climate evolution of the Lake Telmen basin, north central Mongolia, based on palynological data. Quaternary Research 59, 353-363.

Frechen, M., Schweitzer, U., Zander, A., 1996. Improvements in sample preparation for the fine grain technique. Ancient TL 14, 15-18.

Galbraith, R.F., Roberts, R.G., Laslett, G., Yoshida, H., Olley, J.M., 1999. Optical dating of single and multiple grains of quartz from Jinmium rock shelter, northern Australia: part I, experimental design and statistical models. Archaeometry 41, 339-364.

Ganyushkin, D., Chistyakov, K., Volkov, I., Bantcev, D., Kunaeva, E., Brandová, D., Raab, G., Christl, M., Egli, M., 2018. Palaeoclimate, glacier and treeline reconstruction based on geomorphic evidences in the Mongun-Taiga massif (south-eastern Russian Altai) during the Late Pleistocene and Holocene. Quaternary International 470, 26-37.

Gillespie, A.R., Burke, R.M., Komatsu, G., Bayasgalan, A., 2008. Late Pleistocene glaciers in Darhad basin, northern Mongolia. Quaternary Research 69, 169-187.

Gribenski, N., Jansson, K.N., Lukas, S., Stroeven, A.P., Harbor, J.M., Blomdin, R., Ivanov, M.N., et al., 2016. Complex patterns of glacier advances during the late glacial in the Chagan Uzun Valley, Russian Altai. Quaternary Science Reviews 149, 288-305.

Gribenski, N., Jansson, K.N., Preusser, F., Harbor, J.M., Stroeven, A.P., Trauerstein, M., Blomdin, R., et al., 2018. Re-evaluation of MIS 3 glaciation using cosmogenic radionuclide and single grain luminescence ages, Kanas Valley, Chinese Altai. Journal of Quaternary Science 33, 55-67.

Grichuk, V.P., 1997. Late Cenozoic changes of flora in extratropical Eurasia in the light of paleomagnetic stratigraphy. In: Aguirre, E., Pasini, G., van Couvering, J.A., Alekseev, M.N. (Eds.), The Pleistocene Boundary and the Beginning of the Quaternary. Cambridge University Press, Cambridge, pp. 104-113. 
Grubov, V.I., 2011. Key to the Vascular Plants of Mongolia (with an Atlas). Science Publishers, Enfield, NH.

Grunert, J., Lehmkuhl, F., 2004. Aeolian sedimentation in arid and semi-arid environments of Western Mongolia. In: Smykatz, W., Felix-Henningsen, P. (Eds.), Palaeoecology of Quaternary Drylands. Springer, Berlin, pp. 195-218.

Grunert, J., Lehmkuhl, F., Walther, M., 2000. Paleoclimatic evolution of the Uvs Nuur basin and adjacent areas (western Mongolia). Quaternary International 65-66, 171-192.

Gunin, P.D., Vastokova, E.A., Dorofeyuj, N.I., Tarasov, P.E., Black, C.C. (Eds.), 1999. Vegetation Dynamics of Mongolia. Kluwer Academic, Dordrecht, Netherlands.

Herzschuh, U., 2006. Palaeo-moisture evolution in monsoonal Central Asia during the last 50,000 years. Quaternary Science Reviews 25, 163-178.

Heyman, J., Stroeven, A.P., Harbor, J.M., Caffee, M.W., 2011. Too young or too old: evaluating cosmogenic exposure dating based on an analysis of compiled boulder exposure ages. Earth and Planetary Science Letters 302, 71-80.

Hilbig, W., 1995. The Vegetation of Mongolia. SPB Academic, Amsterdam.

Hövermann, J., 1998. Zur Paläoklimatologie Zentsiens-Quantitative Bestimmung von Paläoniederschlag und Temperatur. Petermanns Geographische Mitteilungen 142, 251-257.

Hülle, D., Hilgers, A., Radtke, U., Stolz, C., Hempelmann, N., Grunert, J., Felauer, T., Lehmkuhl, F., 2010. OSL dating of sediments from the Gobi Desert, southern Mongolia. Quaternary Geochronology 5, 107-113.

Huntley, D., Baril, M., 1997. The K content of the K-feldspars being measured in optical dating or in thermoluminescence dating. Ancient TL 15, 11-13.

Huntley, D.J., Lamothe, M., 2001. Ubiquity of anomalous fading in $\mathrm{K}$-feldspars and the measurement and correction for it in optical dating. Canadian Journal of Earth Sciences 38, 1093-1106.

Jäger, E.J., 2005. The occurrence of forest plants in the desert mountains of Mongolia and their bearing on the history of the climate. Erforschung biologischer Ressourcen der Mongolei 9, 237-245.

Juggins, S., 2007. C2: Software for Ecological and Palaeoecological Data Analysis and Visualisation. Version 1.5 User Guide. School of Geography, Politics and Sociology, Newcastle University, Newcastle upon Tyne.

Kamp, U., Krumwiede, B., McManigal, K., Pan, C., Walther, M., Dashtseren, A., 2013a. The Glaciers of Mongolia. Institute of Arctic and Alpine Research University of Colorado at Boulder, Boulder, CO.

Kamp, U., McManigal, K.G., Dashtseren, A., Walther, M., 2013b. Documenting glacial changes between 1910, 1970, 1992 and 2010 in the Turgen Mountains, Mongolian Altai, using repeat photographs, topographic maps, and satellite imagery. Geographical Journal 179, 248-263.

Karger, D.N., Conrad, O., Böhner, J., Kawohl, T., Kreft, H., Soria-Auza, R.W., Zimmermann, N.E., Linder, H.P., Kessler, M., 2017. Climatologies at high resolution for the Earth's land surface areas. Scientific Data 4, 170122.

Khandsuren, P., Seong, Y.B., Oh, J.S., Rhee, H.H., Sandag, K., Yu, B.Y., 2019. Late Quaternary glacial history of Khentey Mountains, Central Mongolia. Boreas 48, 779-799.

Klinge, M., 2001. Glazialgeomorphologische Untersuchungen im Mongolischen Altai als Beitrag zur jungquartären Landschaftsund Klimageschichte der Westmongolei. Geographisches Institut der RWTH Aachen, Aachen.
Klinge, M., Böhner, J., Lehmkuhl, F., 2003. Climate patterns, snow- and timberlines in the Altai Mountains, Central Asia. Erdkunde 57, 296-308.

Klinge, M., Dulamsuren, C., Erasmi, S., Karger, D.N., Hauck, M., 2018. Climate effects on vegetation vitality at the treeline of boreal forests of Mongolia. Biogeosciences 15, 1319-1333.

Klinge, M., Lehmkuhl, F., 2013. Geomorphology of the Tsetseg Nuur basin, Mongolian Altai-lake development, fluvial sedimentation and aeolian transport in a semi-arid environment. Journal of Maps 9, 361-366.

Klinge, M., Lehmkuhl, F., Schulte, P., Hülle, D., Nottebaum, V., 2017. Implications of (reworked) aeolian sediments and paleosols for Holocene environmental change in western Mongolia. Geomorphology 292, 59-71.

Klinge, M., Sauer, D., 2019. Spatial pattern of Late Glacial and Holocene climatic and environmental development in Western Mongolia - a critical review and synthesis. Quaternary Science Reviews 210, 26-50.

Lehmkuhl, F., 2012. Holocene glaciers in the Mongolian Altai: an example from the Turgen-Kharkhiraa Mountains. Journal of Asian Earth Sciences 52, 12-20.

Lehmkuhl, F., Grunert, J., Hülle, D., Batkhishig, O., Stauch, G., 2018. Paleolakes in the Gobi region of southern Mongolia. Quaternary Science Reviews 179, 1-23.

Lehmkuhl, F., Haselein, F., 2000. Quaternary paleoenvironmental change on the Tibetan Plateau and adjacent areas (western China and western Mongolia). Quaternary International 65-66, 121-145.

Lehmkuhl, F., Klinge, M., 2000. Bodentemperaturmessungen aus dem Mongolischen Altai als Indikatoren für periglaziale Geomorphodynamik in hochkontinentalen Gebrigsräumen. Zeitschrift für Geomorphologie N.F. 44, 75-102.

Lehmkuhl, F., Klinge, M., Rother, H., Hülle, D., 2016. Distribution and timing of Holocene and late Pleistocene glacier fluctuations in western Mongolia. Annals of Glaciology 57, 169-178.

Lehmkuhl, F., Klinge, M., Stauch, G., 2004. The extent of Late Pleistocene glaciations in the Altai and Khangai Mountains. In: Ehlers, J., Gibbard, P.L. (Eds.), Quaternary Glaciations-Extent and Chronology. Part 3, South America, Asia, Africa, Australia, Antarctica. Elsevier, Amsterdam, pp. 243-254.

Lehmkuhl, F., Klinge, M., Stauch, G., 2011. The extent and timing of Late Pleistocene glaciations in the Altai and neighbouring mountain systems. In: Ehlers, J., Gibbard, P.L., Hughes, P.D. (Eds.), Quaternary Glaciations-Extent and Chronology: A Closer Look. Elsevier, Amsterdam, pp. 967-979.

Lehmkuhl, F., Lang, A., 2001. Geomorphological investigations and luminescence dating in the southern part of the Khangay and the Valley of the Gobi Lakes (central Mongolia). Journal of Quaternary Science 16, 69-87.

Lenarczyk, J., Kołaczek, P., Jankovská, V., Turner, F., KarpińskaKołaczek, M., Pini, R., Pedziszewska, A., Zimny, M., Stivrins, N., Szymczyk, A., 2015. Palaeoecological implications of the subfossil Pediastrum argentinense-type in Europe. Review of Palaeobotany and Palynology 222, 129-138.

Ma, Y., Liu, K.-b., Feng, Z.-D., Meng, H., Sang, Y., Wang, W., Zhang, H., 2013. Vegetation changes and associated climate variations during the past $\sim 38,000$ years reconstructed from the Shaamar eolian-paleosol section, northern Mongolia. Quaternary International 311, 25-35.

Miehe, G., Schlütz, F., Miehe, S., Opgenoorth, L., Cermak, J., Samiya, R., Jäger, E.J., Wesche, K., 2007. Mountain forest islands and Holocene environmental changes in central Asia: a 
case study from the southern Gobi Altay, Mongolia. Palaeogeography, Palaeoclimatology, Palaeoecology 250, 150-166.

Moore, P.D., Webb, J.A., Collinson, M.E., 1991. Pollen Analysis. Blackwell, Oxford.

Murray, A.S., Wintle, A.G., 2000. Luminescence dating of quartz using an improved single-aliquot regenerative-dose protocol. Radiation Measurements 32, 57-73.

Naumann, S., 1999. Spät- und postglaziale Landschaftsentwicklung im Bajan Nuur Seebecken (Nordwestmongolei) Lateand postglacial landscape evolution in the Bay an Nuur lake basin (northwestern Mongolia). Die Erde 130, 117-130.

Nelson, M.S., Rittenour, T.M., 2015. Using grain-size characteristics to model soil water content: application to dose-rate calculation for luminescence dating. Radiation Measurements 81, 142149.

Peck, J.A., Khosbayar, P., Fowell, S.J., Pearce, R.B., Ariunbileg, S., Hansen, B.C.S., Soninkhishig, N., 2002. Mid to Late Holocene climate change in north central Mongolia as recorded in the sediments of Lake Telmen. Palaeogeography, Palaeoclimatology, Palaeoecology 183, 135-153.

Philippsen, B., Heinemeier, J., 2013. Freshwater reservoir effect variability in northern Germany. Radiocarbon 55, 1085-1101.

Poetsch, S., 2017. Dynamics and Paleo-Climatic Forcing of Late Pleistocene Glaciers in the Turgen and Khangai Mountains (Mongolia) Reconstructed from Geomorphology, ${ }^{10}$ Be Surface Exposure Dating, and Ice Flow Modeling. $\mathrm{PhD}$ thesis, University of Greifswald, Greifswald, Germany.

Prescott, J.R., Hutton, J.T., 1994. Cosmic ray contributions to dose rates for luminescence and ESR dating: large depths and longterm time variations. Radiation Measurements 23, 497-500.

Prokopenko, A.A., Kuzmin, M.I., Williams, D.F., Gelety, V.F., Kalmychkov, G.V., Gvozdkov, A.N., Solotchin, P.A., 2005.

Basin-wide sedimentation changes and deglacial lake-level rise in the Hovsgol basin, NW Mongolia. Quaternary International 136, 59-69.

Reimer, P.J., Bard, E., Bayliss, A., Beck, J.W., Blackwell, P.G., Ramsey, C.B., Buck, C.E., et al., 2013. IntCal13 and Marine13 radiocarbon age calibration curves $0-50,000$ years cal BP. Radiocarbon 55, 1869-1887.

Reuther, A.U., Herget, J., Ivy-Ochs, S., Borodavko, P., Kubik, P.W., Heine, K., 2006. Constraining the timing of the most recent cataclysmic flood event from ice-dammed lakes in the Russian Altai Mountains, Siberia, using cosmogenic in situ ${ }^{10}$ Be. Geology 34, 913.

Roe, G., 2009. On the interpretation of Chinese loess as a paleoclimate indicator. Quaternary Research 71, 150-161.

Rother, H., Lehmkuhl, F., Fink, D., Nottebaum, V., 2014. Surface exposure dating reveals MIS-3 glacial maximum in the Khangai Mountains of Mongolia. Quaternary Research 82, 297-308.

Rudaya, N., Li, H.-C., 2013. A new approach for reconstruction of the Holocene climate in the Mongolian Altai: the high-resolution $\delta^{13} \mathrm{C}$ records of TOC and pollen complexes in Hoton-Nur Lake sediments. Journal of Asian Earth Sciences 69, 185-195.

Rudaya, N., Tarasov, P.E., Dorofeyuk, N., Solovieva, N., Kalugin, I., Andreev, A., Daryin, A., Diekmann, B., Riedel, F., Tserendash, N., 2009. Holocene environments and climate in the Mongolian Altai reconstructed from the Hoton-Nur pollen and diatom records: a step towards better understanding climate dynamics in Central Asia. Quaternary Science Reviews 28, 540-554.

Schlütz, F., Dulamsuren, C., Wieckowska, M., Mühlenberg, M., Hauck, M., 2008. Late Holocene vegetation history suggests natural origin of steppes in the northern Mongolian mountain taiga.
Palaeogeography, Palaeoclimatology, Palaeoecology 261, 203 217.

Smith, S.G., Wegmann, K.W., Ancuta, L.D., Gosse, J.C., Hopkins, C.E., 2016. Paleotopography and erosion rates in the central Hangay Dome, Mongolia: landscape evolution since the midMiocene. Journal of Asian Earth Sciences 125, 37-57.

Stuiver, M., Reimer, P.J., 1993. Extended ${ }^{14} \mathrm{C}$ database and revised CALIB radiocarbon calibration program. Radiocarbon 35, 215-230.

Sun, A., Feng, Z.-D., Ran, M., Zhang, C., 2013. Pollen-recorded bioclimatic variations of the last $\sim 22,600$ years retrieved from Achit Nuur core in the western Mongolian Plateau. Quaternary International 311, 36-43.

Thiel, C., Buylaert, J.-P., Murray, A., Terhorst, B., Hofer, I., Tsukamoto, S., Frechen, M., 2011. Luminescence dating of the Stratzing loess profile (Austria) - testing the potential of an elevated temperature post-IR IRSL protocol. Quaternary International 234, 23-31.

Thomsen, K.J., Murray, A.S., Jain, M., Bøtter-Jensen, L., 2008. Laboratory fading rates of various luminescence signals from feldspar-rich sediment extracts. Radiation Measurements 43, 1474-1486.

Tian, F., Herzschuh, U., Telford, R.J., Mischke, S., van der Meeren, T., Krengel, M., Richardson, J., 2014. A modern pollen-climate calibration set from central-western Mongolia and its application to a late glacial-Holocene record. Journal of Biogeography 41, 1909-1922.

Unkelbach, J., Dulamsuren, C., Punsalpaamuu, G., Saindovdon, D., Behling, H., 2017. Late Holocene vegetation, climate, human and fire history of the forest-steppe-ecosystem inferred from core G2-A in the "Altai Tavan Bogd" conservation area in Mongolia. Vegetation History and Archaeobotany 67, 394.

Unkelbach, J., Kashima, K., Enters, D., Dulamsuren, C., Punsalpaamuu, G., Behling, H., 2019. Late Holocene (Meghalayan) palaeoenvironmental evolution inferred from multi-proxy-studies of lacustrine sediments from the Dayan Nuur region of Mongolia. Palaeogeography, Palaeoclimatology, Palaeoecology 530, 1-14.

Walther, M., 1999. Befunde zur jungquartären Klimaentwicklung rekonstruiert am Beispiel der Seespiegelstände des Uvs NuurBeckens (NW-Mongolei). Die Erde 130, 131-150.

Wang, F., Chien, N., Zhang, Y., Yang, H., 1995. Pollen Flora of China. 2nd ed. [In Chinese.] Science Press, Beijing.

Wang, J., Zhu, L., Wang, Y., Peng, P., Ma, Q., Haberzettl, T., Kasper, T., Matsunaka, T., Nakamura, T., 2017. Variability of the ${ }^{14} \mathrm{C}$ reservoir effects in Lake Tangra Yumco, central Tibet (China), determined from recent sedimentation rates and dating of plant fossils. Quaternary International 430, 3-11.

Wesche, K., Ambarlı, D., Kamp, J., Török, P., Treiber, J., Dengler, J., 2016. The Palaearctic steppe biome: a new synthesis. Biodiversity and Conservation 25, 2197-2231.

Wintle, A.G., 1973. Anomalous fading of thermo-luminescence in mineral samples. Nature 245, 143-144.

Xu, X., Yang, J., Dong, G., Wang, L., Miller, L., 2009. OSL dating of glacier extent during the last glacial and the Kanas Lake basin formation in Kanas River valley, Altai Mountains, China. Geomorphology 112, 306-317.

Yabuki, H., Ohata, T., 2009. The recent glacier changes in Mongolian Altai Mountains. American Geophysical Union Fall Meeting Abstracts, December 14-18, 2009, C31C-0454. San Francisco, California.

Yang, X., Preusser, F., Radtke, U., 2006. Late Quaternary environmental changes in the Taklamakan Desert, western China, 
inferred from OSL-dated lacustrine and aeolian deposits. Quaternary Science Reviews 25, 923-932.

Yan, Y., Xu, X., Xin, X., Yang, G., Wang, X., Yan, R., Chen, B., 2011. Effect of vegetation coverage on aeolian dust accumulation in a semiarid steppe of northern China. Catena 87, 351-356.

Yu, K., Lehmkuhl, F., Schlütz, F., Diekmann, B., Mischke, S., Grunert, J., Murad, W., Nottebaum, V., Stauch, G., Zeeden, C.,
2019. Late Quaternary environments in the Gobi Desert of Mongolia: vegetation, hydrological, and palaeoclimate evolution. Palaeogeography, Palaeoclimatology, Palaeoecology 514, 77-91.

Zhao, J., Yin, X., Harbor, J.M., Lai, Z., Liu, S., Li, Z., 2013. Quaternary glacial chronology of the Kanas River valley, Altai Mountains, China. Quaternary International 311, 44-53. 